\title{
Examining the Perceptions and Preferences of Saudi EFL Student Teachers Concerning Teachers' Feedback Practices
}

\author{
Hayat Rasheed Hamzah Alamri \\ Curricula \& Teaching Methods Dep., College of Education, Taibah University \\ PO box 4532, Madinah 41412, Kingdom of Saudi Arabia
}

\begin{abstract}
This study examines the perceptions of thirty-one Saudi female EFL student teachers of the importance of teacher feedback practices, along with their preferences for different types and delivery methods. The students were following the Analysis of EFL Curriculum course run by the College of Education at Taibah University, which has adapted the Project-Based-Learning (PBL) approach. Data was gathered by means of three 5-point Likert scale questionnaires. The results of the descriptive statistics revealed that the majority of the participants had moderate to high positive perceptions and preferences towards the different types and delivery methods of teacher feedback. In addition, they expressed a high level of satisfaction with the course in general. The results of the quantitative data revealed that the students also recognized the value of teacher feedback for their subsequent assignments and courses. Moreover, they highlighted the need for additional meetings between students and teachers to discuss feedback relating to assignments, tests, activities and/or projects. Likewise, the EFL student teachers expressed their desire for more written feedback on their work, along with further opportunities to ask questions, share information, and discuss issues with their teachers and peers. It was also notable that the majority of respondents valued the importance of teacher feedback as an effective and preferable complementary source of knowledge in EFL classrooms.
\end{abstract}

Keywords: EFL student teachers, perceptions, preferences, satisfaction, teacher feedback

\section{Introduction}

Feedback forms a crucial aspect of language learning and teaching (Seker \& Dincer, 2014). It was defined by Narciss (2008) as being "all post-response information that is provided to a learner to inform [about] his or her actual state of learning or performance" (p.127). Feedback is implemented during the teaching and learning process to improve students' performance, encourage motivation, and stimulate thinking skills (Kavaliauskienė \& Anusienè, 2012; Orts \& Salazar, 2016). Recently, Dargusch and Davis (2015) added that feedback makes a broad contribution to the improvement of learning, as a result of the exchangeable roles of teachers and students, as well as the sharing of responsibilities. Moreover, Petchprasert (2012) concluded that feedback supports both teachers and their students in meeting the goals set for courses, resulting in high levels of success.

Previous research has examined the use of feedback in higher education as a successful tactic and source of knowledge provided by the teacher to the students. A significant study by Carless (2006) reported that feedback "acts by providing advice for improvement of the current assignment; advice for improvement of future assignments; explaining or justifying a grade; and an act by which the tutor demonstrates characteristics, such as expertise, diligence or authority" (p. 220). According to Rowe and Wood (2008), universities need to recognize feedback as an important component of: firstly, improving the ranking of learning and teaching and secondly, as an indicator of reaching the high standards set by the quality assurance system.

The research results have reported students as being willing to utilize feedback as a tool for student-teacher interaction (Şeker \& Sezgin, 2013). Moreover, students indicated their need for different types of teacher feedback, as appropriate (Kahraman \& Yalvaç, 2015), as well as a strong need for such feedback, even if provided on an infrequent basis and/or with insufficient comments (Sharif \& Zainuddin, 2017).

A number of studies over the previous two decades have investigated learners' preferences and perceptions in relation to teacher feedback. The results of a seminal study conducted by Grami (2005) indicated that Saudi EFL students expected feedback from their teachers, believing this resulted in considerable benefit. Furthermore, Park (2010) noted the need for university teachers to become aware of student teachers' preference for feedback for many characteristics of learning, i.e. learning styles, proficiency levels and motivation. Additionally, Norouzian and Farahani (2012) indicated that the results of perception and preference studies can raise the awareness of language instructors of the reaction of students towards the feedback practices of EFL teachers. This awareness can, in turn, provide EFL teachers with appropriate learning environments, aimed at improving both the motivation and performance of learners. Similarly, Seker and Dincer (2014) suggested a need for teachers to make cautious decisions (i.e. by integrating students' perceptions and preferences) when attempting to shape the feedback process. Kaivanpanah, Alavi, and Sepehrinia (2015) concluded that "teachers will be able to create a more effective and involving learning environment by attending to their students' reactions and feelings, and considering students' preferences along with their own teaching experience" (p.90).

A growing body of research has recently been undertaken within the context of higher education, focusing 
on students' preferences towards, and perceptions of, feedback (e.g. Chen, Nassaji \& Liu, 2016; Kaur \& Singh, 2016; Mungungu-Shipale \& Kangira, 2017; Orts \& Salazar, 2016; Sharif \& Zainuddin, 2017; Vasu, Ling \& Nimehchisalem, 2016; Zhan, 2016). This has partially arisen from the discussion taking place in the existing literature of the vital role played by feedback.

Despite the positive attitudes, perceptions and beliefs of university students towards the wide-ranging impact of teacher feedback on their academic development (e.g. Fakeye, 2016; Kahraman \& Yalvaç, 2015; Papangkorn, 2015; Parkes \& Fletcher, 2016), it has also been documented that feedback interventions can fail to result in an increase in learning performance (e.g. Mungungu-Shipale \& Kangira, 2017; Rahimi, 2010; Rowe, Wood \& Petocz, 2008). These studies have reported a number of factors relating to the limited effectiveness of feedback practices. Firstly, a lack of engagement from teaching staff has a negative impact on the improvement of feedback practices (Rowe, Wood, \& Petocz, 2008). Secondly, there is a limited amount of teacher feedback, which is considered unhelpful, particularly due to the lack of detailed comments (Rahimi, 2010). Thirdly, a large scale study by Ferguson (2011) considered that the majority of university students indicated receiving only brief and concise feedback, which was also of low quality. Finally, a recent study by Mungungu-Shipale and Kangira (2017) reported that feedback may not always be particularly effective, and that the final decision concerning the most appropriate approach tends to be left to the individual teacher.

However, academic staff creating teacher preparation programs need to be aware of the requirement to create an effective learning environment, including setting up sessions to discuss the appearance of errors and elicit suggestions for further improvement. Postgraduate student teachers require assistance in developing constructive academic features (i.e. trust, belief, and action), as their absence can have a negative influence on the quality, processes and procedures of higher education, and thus the progress of their future careers (Dargusch \& Davis, 2015). EFL student teachers are expected, as part of their professional preparation, to carry out different types of feedback (including methods of delivery) in their own classrooms. This enables them to simultaneously play the dual role of student and professional. Moreover, as a new generation of teachers, they are required to be capable of basing their decisions concerning the delivery of feedback to their students on practices they have been taught, along with personal experience.

This study therefore responds to the importance of investigating the perceptions and preferences of higher education students towards teacher feedback noted above, along with the inadequate and unsatisfactory quality of existing feedback. It therefore focuses on the perceptions of Saudi EFL student teachers concerning the importance of teacher feedback and their preference for different types and delivery methods.

\section{Statement of the Problem}

One of the obligatory courses in the postgraduate Educational Diploma Program (EDP) in the College of Education at Taibah University is an analysis of the EFL Curriculum. The researcher is a teacher of this course, and has adopted Project-Based Learning (PBL) as an effective method of fulfilling the learning outcomes of the course. In order to become more effective, the PBL method requires the inclusion of both lectures and feedback sessions, in which learners can be provided with information concerning different types (and delivery methods) of feedback, while working on their course projects.

Feedback remains a relatively underexplored subject, despite students' recognition of its vital impact on learning. It thus faces a number of challenges, including: (1) quality; (2) quantity; (3) time; and (4) a lack of clear requirements and expectations. In addition, little attention has been paid to providing learners with regular feedback that is both planned and encouraging. During a free discussion regarding the importance of feedback, Saudi female EFL student teachers in EDP reported a considerable absence of feedback during other courses in relation to their projects or tasks. In addition, they also stated that some teachers requested final drafts for grading without giving any pre- or post-feedback. They noted that this approach creates an insecure atmosphere and causes both dissatisfaction and confusion. Previous research (Hattie \& Timperley, 2007; Kaivanpanah et al., 2015; Rowe \& Wood, 2008) suggested that feedback is most effective when it clearly identifies strengths and weaknesses and is delivered immediately following the performance of a task. This motivates students to develop their learning skills, while also providing them with practical considerations for further improvement.

The main purpose of this current study is therefore to explore the perceptions of Saudi female EFL student teachers towards: firstly, the importance of teacher feedback practices and secondly, their preferences for different types and delivery methods during their course projects. Finally, the study aims to identify the general level of satisfaction of EFL student teachers concerning the course delivery.

\section{The Research Questions}

1. What are the perceptions of Saudi EFL female student teachers concerning the importance of teacher feedback practices provided during their course project?

2. What are the Saudi EFL female student teachers' preferences concerning the types of teacher feedback provided during their course project? 
3. What are the Saudi EFL female student teachers' preferences concerning the delivery methods of teacher feedback provided during their course project?

4. What are the levels of satisfaction of the Saudi EFL female student teachers towards the course in general?

\section{Significance of the Study}

This study will facilitate the awareness of teachers of the need to tailor their types and delivery methods of feedback, taking into account the perceptions and preferences of their students. It will also give teachers insights on how, what, and when to deliver effective feedback to their students, in order to improve their academic performance. Moreover, the results of the study identifies the most powerful and efficient types and delivery methods of teacher feedback, particularly during project-based courses, in order to successfully enhance students' performance and develop their skills.

\section{Literature Review}

Two areas of research underpin the research questions and inform this paper: (1) teacher feedback and (2) the perception and preferences of learners. There is a brief overview of the importance, characteristics of effective teacher feedback, as well as the role of feedback in PBL. In addition, there is a review of the different feedback types and delivery methods. Finally, the researcher summarizes the views of previous studies of learners' perceptions and preferences in relation to teacher feedback.

\subsection{Importance of teacher feedback for learning}

According to Hattie and Timperley (2007), "feedback is conceptualized as information provided by an agent (e.g. teacher, peer, book, parent, self, experience) regarding aspects of one's performance or understanding (p. 81)." Nation (2009) and Susanti (2013) identified the existence of various different sources of feedback in education, i.e. teacher, peers, and self-feedback. Moreover, Nation (2009) noted that the source, delivery mode and form of feedback would determine whether it is delivered as spoken, written, or both.

Higher education students frequently request a detailed analysis of their work, in order to determine its strengths and weaknesses. They also ask to be provided with regular in-depth feedback contributing to further development (Hewitt, 2008). Thus, effective learning requires feedback that is comprehensible, beneficial and relevant (Hill \& Flynn, 2006).

The review of a considerable number of studies revealed little agreement on the importance and value of feedback practices implemented during the teaching-learning process.

Truscott (1996) rejected the existence of any positive impact of written feedback given by teachers to improve their students' writing. Moreover, Truscott argued that teachers should adopt a 'correction-free approach' in their classrooms, so as to improve the attitudes of students. The result of his quasi-experimental study revealed that the control group achieved significantly higher scores in marking sentence boundaries, despite the experimental group having been given an extensive ten-week correction period. Truscott therefore concluded that correction can prove ineffective and harmful to students' learning. In response to Truscott's results, Ferris (1999) provided evidence of the positive influence of error feedback in L2 writing. She based her arguments on the positive results from surveying students' opinions concerning teacher feedback, which indicated that L2 students value the importance of correction from their teacher. Furthermore, Ferris (1999) concluded that the absence of any type of feedback has a serious negative impact on students' need to improve their editing skills.

The findings of a study conducted by Grami (2005) demonstrated that Saudi EFL students agreed on the importance of feedback from their teachers, and paid it a great deal of attention. The results of Morss and Murray (2005) revealed that teacher written feedback makes the marking process more transparent for students, as well as assisting them to accept the marks awarded.

The results of an interview conducted by Carless (2006), revealed that students valued feedback comments that resulted in a rapid improvement of both current and future tasks requiring similar skills. Additionally, Zacharias (2007) stated that students view teacher feedback as a valuable method for achieving improved grades and comments.

Rowe and Wood (2008) found that many students reported that their anxiety was reduced by timely and individual teacher feedback. Furthermore, they valued teacher feedback that considered their needs, feelings and point of view. Responses obtained from a study conducted by Rowe et al. (2008) revealed that teacher feedback had a positive impact on the quality of students' experience, as well as helping them to reflect on their own learning. Furthermore, Westwood (2008) reported that teacher feedback motivates students and informs them of their progress, including identifying the most important aspects to ensure further improvement. After examining the importance of teacher feedback in relation to different types of error, Rahimi (2010) revealed that the majority of EFL students expected and valued their teachers' written feedback concerning various different types 
of errors.

Susanti (2013) viewed teacher feedback as developing students' learning autonomy, while controlling their initiation into being subject to correction. The results of a study by Dargusch and Davis (2015) found that feedback plays an essential role in learning and (more particularly) in the field of teacher training. This is due to feedback being a professional practice that students themselves will enact as part of their future professional role. Nuramirah (2017) reported that feedback plays a facilitative role in learning, arising from the provision of opportunities for comprehensible input, comprehensible output, and feedback.

In conclusion, these studies confirm that both students and teachers agree that teacher feedback shows some evidence of having a positive influence. Moreover, teachers need to be aware of the importance of feedback to promote learning and facilitate improvement. They therefore need to demonstrate a professional approach when modelling their feedback practices.

\subsection{Characteristics of effective teacher feedback}

Teacher feedback needs to indicate certain characteristics as being effective. Morss and Murray (2005) concluded that a teacher's comments should be sufficiently clear and be careful to avoid additional confusion for his/her students. In addition, it is essential for teachers to engage with students in a healthy and interactive discussion of their mistakes and comments. Hill and Flynn (2006, p.6) suggested four features of providing teacher feedback to students. Firstly, feedback should be corrective in nature and provide students with comprehensive information on their work. Secondly, in order to be effective, it is essential that feedback is undertaken in a timely manner, with delayed feedback resulting in a lower levels of academic improvement. Thirdly, feedback should compare students' performance to a specific academic goal (i.e. criterion-referenced feedback), rather than to their peers (i.e. norm-referenced feedback). Fourthly, teachers should encourage students to develop their own feedback through ongoing self-assessment of their performance. Brown and Glover (2006) assumed the existence of some conditions under which feedback may influence students' learning. They believed that sufficient levels of feedback can clarify what constitutes good performance for the learner, i.e. goals, criteria and expected standards. Moreover, if provided with sufficient rapidity, feedback can facilitate the development of self-assessment (i.e. reflection) in learning, while relating feedback to the purpose of the assignment and its criteria encourages teacher and peer dialogue. They added that feedback aimed at improving students' work or learning should provide information to teachers capable of shaping their teaching. Westwood (2008) added that feedback should be delivered in positive emotional tone, in order to ensure that students feel safe and secure when asking for assistance. Likewise, Ferguson (2011) indicated the importance of careful consideration of the amount of feedback given on a draft, as it may overwhelm students if too detailed, but, if too concise, it may result in only limited benefit.

In summary: it is vital that teacher feedback is delivered in a manner that is clear, timely, positive and encouraging, as well as sufficient, reflective, and seeking to ensure the satisfaction of students.

\subsection{Role of feedback in PBL}

One of the major changes to higher education during the second half of the twentieth century is the move to become more learner-centred (Boud, 2006, p. 19). PBL is a prime example of this change, being a constructivistbased method aimed at enhancing engagement in the learning process (Hixson, Ravitz \& Whisman, 2012). PBL is based on John Dewey's call to implement learning through experience, and to incentivize students through the employment of 'hands-on' experiences, to extend learners' knowledge of the curriculum, while at the same time increasing the number of related skills, i.e. collaboration, problem-solving, critical thinking, and reflection (Baş \& Beyhan, 2010; Holm, 2011; Pieratt, 2010; Solomon, 2003). PBL was described by Grant (2011) as an "instructional method that affords authentic learning tasks grounded in the personal interests of learners" (p. 38). Ravitz (2010) defined PBL as "an approach to instruction featuring (a) in-depth inquiry, (b) over an extended period, (c) that is a student self-directed to some extent, and (d) that requires a formal presentation of results" (p. 293).

The literature considers PBL to possess a number of features benefitting learning. Bas (2011) found PBL to be more effective than traditional instruction for improving the level of learners' academic achievements, attitude and motivation. Wrigley (1998) and Ravitz (2010) added that this method: (1) encourages learners to support each other in the acquisition of knowledge; (2) enables them to gain insights capable of being employed in other situations; and (3) instils the skills required to successfully undertake public presentations.

Simpson (2011) highlighted various further features of PBL, including its emphasis on: (1) exploring new knowledge; (2) creating a student-centred learning setting; (3) increasing the use of questions and problemssolving processes; (4) the provision of frequent project assessment in the form of feedback; (5) ensuring learners share ideas and expertise; and (6) promoting an atmosphere of cooperative learning.

However, Hixson et al. (2012), Şat (2013), and Thomas (2000) emphasized the key benefits of PBL as being the learning in depth, along with intrinsic motivation and a complete focus on a student-centred approach. 
Hasani, Hendrayana and Senjaya (2017) considered the crucial benefits of PBL as being the introduction of learners to methods of gathering data and developing creative products, as well as building related skills. A number of further studies (Grant, 2011; Hüttel \& Gnaur, 2017; Pieratt, 2010; Tamba, Motlan \& Turnip, 2017) have pointed out that PBL enhances both the creative thinking and problem-solving skills of learners, as well, as awarding opportunities for learners to guide, manage, and monitor their learning. Moreover, PBL promotes complex and transformative learning, with the ability to encourage the productive capacity of learners, alongside respecting their freedom to select tasks based on their own interests and creative skills.

Larmer and Mergendoller (2010) identified seven essential elements needed to ensure PBL is practical for learners, including: (1) familiarity with the project area; (2) enhancing learner's decision-making; and (3) mastering twenty-first century skills, i.e. collaboration, communication, motivation, feedback and product presentation. Moreover, these elements require that certain roles are played by both teachers and learners. Moss and Van Duzer (1998) highlighted that PBL requires teachers to exercise careful planning and flexibility, and in particular an awareness of the dynamic nature of PBL to solve problems, find solutions, and convey learning in a setting that is both stimulating and challenging. A number of further researchers (Thomas, 2000; Wrigley, 1998; Zancul, Sousa-Zomer \& Cauchick-Miguel, 2017) have attempted to present the role of the teacher in a PBL environment as a facilitator of learning, a guide of project process, and a provider of resources. In addition, the teacher is required to be a good listener, to enable him/her to discuss and answer learners' questions. Moreover, Pieratt (2010) summarized the role of the teacher as focusing his/her attention on learners' interests and abilities, in order to improve their engagement in the learning process. Holm (2011) argued that in PBL, the teacher must provide learners with scaffolding and strategic instructions.

Thus, learners may experience a number of difficulties and challenges in creating high-quality products within the context of PBL. This led Postholm (2005) to claim that "students' voices should be heard in the classroom, and that they should be treated as responsible learners who need to find out what they want from their learning and develop their competences" (p. 533). Thus, the teacher needs to provide learners with appropriate and authentic feedback. Teacher feedback has, in the context of PBL the potential to facilitate the learning processes in a number of different ways. Reviewing students' project drafts assists learners to reflect on their own work and improve their project performance. In addition, teachers are required to monitor learners' development, including providing frequent feedback, and continually assessing product-based learning outcomes. Moreover, Clark (2006) emphasized the need for teachers to help learners examine their own ideas and construct their own products. Simpson (2011) demonstrated that teachers can motivate their students by giving them the opportunity to question, imagine, and challenge each other, thus encouraging them to fully engage in deep learning.

Moss and Van Duzer (1998) emphasized the role played by learners' ability to plan, organize, and negotiate in the PBL environment, as well as making decisions about their final product. Likewise, Thomas (2000) described their role as working hard to identify problems, find solutions, and create an end-product, i.e. presentations, reports and inventions. Similarly, Solomon (2003) recommended that learners in PBL take full responsibility for tasks-at-hand and collect the recommended information to facilitate the analysis, synthesis and finalization of products. According to Grant (2011), learners need to be successfully motivated in a PBL setting, including reflecting on their own knowledge, collaborating with team members, and self-regulating their learning skills.

\subsection{Types and delivery methods of feedback}

There are a number of different forms of feedback, including: (1) effective; (2) interpretive; (3) diagnostic; (4) corrective; (5) descriptive; (7) evaluative; (8) motivational; and (9) exploratory. To meet the purpose of the current study, this literature review focusses specifically on types 4 to 9 .

The most common type of teacher feedback is corrective feedback (Hattie \& Timperley, 2007). In general, learners expect more knowledge and information from their teachers when it comes to their proficiency for the task-in-hand. Several studies investigating the attitudes towards, and views on, corrective feedback (Fakeye, 2016; Kaivanpanah et al., 2015; Park, 2010) reported that both EFL teachers and learners highlighted the need for oral and written corrective feedback. Furthermore, a substantial body of research has revealed the positive perceptions and preferences of both EFL teachers and learners of corrective feedback (Mungungu-Shipale \& Kangira, 2017), as well as the positive value of different delivery methods of teacher corrective feedback to EFL learners (Chen et al., 2016; Jodaie, 2014; Kahraman \& Yalvaç, 2015; Sopin, 2015). The results of the abovecited studies reveal that corrective feedback supports learners' self-correction, following the initial feedback on their first drafts. Moreover, it contributes to a general improvement in learners' competencies in writing, speaking, grammar skills, as well as academic performance. In addition, corrective feedback engages the learner in a number problem-solving situations, focusing on configuring mistakes and errors. This may therefore improve the complete learning process, resulting in learners gaining the optimum degree of knowledge.

A further detailed form of feedback is known as descriptive feedback. This generally includes the delivery 
of oral or written specific information and knowledge regarding the ways a learner is able to progress in the learning process, based on assessments of tasks-at-hand. A report published by the New South Wales Government (2015) identified the purpose of descriptive feedback as providing: (1) ongoing information to students; (2) identifying strengths, weaknesses, and challenges related to learner outcomes; and (3) providing opportunities to improve learning. Lipnevich and Smith (2009) examined the influence of different types of feedback on the performance of university students working on an essay examination, concluding that learners preferred feedback that was both detailed and descriptive.

Watts (2007) considered evaluative feedback as an essential element of the learning process, noting that "without evaluative feedback, individuals and organizations cannot evolve in ways that meet the standards of others" (p. 384). Hattie and Timperley (2007) assumed that a lack of clarity in evaluative feedback leads to poor performance and causes a low self-image, but that evaluative feedback provides positive or negative comments learners are then able to employ in order to improve their work (New South Wales Government, 2015).

Motivational feedback aims to encourage and satisfy learners, however few up-to-date studies have focused on establishing its importance. Only a small number of studies have explored the factors influencing the impact of motivational feedback. Lee et al. (2013) reported that both intrinsic (i.e. self-achievement and playfulness) and extrinsic (i.e. peer-competition and financial reward) motivational factors demonstrate a degree of positive influence on the quality and quantity of the accomplished tasks. In addition, Abad, Ghosh, Riccardi and Trento (2013) assumed that audio, textual and visual motivational feedback factors positively enhance performance. Defalco, Baker, Paquette, and Georgoulas (2014) designed a preliminary study to explore the impact of the intervention of motivational feedback messages on decreasing students' frustration and improving trainees' engagement and learning outcomes. The findings established methods of creating online sensitive tutoring systems and providing immediate motivational feedback to regulate situations trainees experienced as frustrating and foster learning.

In contrast to research focusing on corrective, descriptive, evaluative and motivational feedback, this current study has been unable to identify any direct literature regarding exploratory feedback. For the purposes of the current research, this type of feedback tends to provide opportunities for posing questions aimed at inspiring learners to think differently and increase their comprehension to a deeper level. Additionally, it opens a space for interaction between learner-learner, learner-teacher, and learner-project content.

When it comes to the medium of delivering feedback, Hattie and Timperley $(2007$, p.102) claimed that educators should first ask "three major questions: Where am I going? How am I going? And Where to next?" because the answers may "enhance learning when there is a discrepancy between what is understood and what is aimed to be understood". Nuramirah (2017) supported this claim of Hattie and Timperley (2007), confirming the significance of the method used by a teacher to deliver feedback, due to its influence on students' responses. Ertmer et al. (2007, p. 413) summarized the benefits of effective feedback for: (1) facilitating learners' selfassessment and reflection; (2) providing valuable and relevant comments to learners about their work; and (3) encouraging positive motivational beliefs and self-esteem. This results in teachers generally selecting different effective and appropriate methods to deliver feedback to the learners.

Hence, several studies have investigated the use of written feedback (Carless, 2006; González, 2010; Grami, 2005; Jodaie, 2014; Kaur \& Singh, 2016; Rahimi, 2010) to convey relevant comments. A number of studies (Hooper, 2010; Merry \& Orsmond, 2008; Parkes \& Fletcher, 2016) have found audio feedback to be an innovative and more effective method of delivering feedback. On the other hand, Ferguson (2011), Kaivanpanah et al. (2015) and Rowe \& Wood (2008) reported the importance of immediate teacher feedback. Only a limited number of studies have investigated the use of: (1) oral teacher feedback as a method of delivery (Ferguson, 2011; Kaivanpanah et al., 2015; Susanti, 2013) and (2) individualized feedback (Douglas et al., 2016; Ferguson, 2011; Şeker \& Sezgin, 2013).

For the purposes of the current study, during the various phases of PBL, the researcher provided the learners with immediate, individual, group and oral feedback, along with written, formal and informal feedback. Each of these methods was implemented in order to achieve a specific goal.

\subsection{Research on learners' perception and preferences towards feedback}

Several recent studies investigating the perceptions of teacher feedback have provided a number of further insights and directions. Grami (2005) undertook a seminal study employing structured questionnaires to examine the perceptions of thirty-five Saudi university EFL students concerning the written feedback from their teachers. The findings indicated that these students clearly preferred this form of feedback and felt they gained a considerable amount of benefit. A study conducted by Dargusch and Davis (2015) focused on teacher training and the perceptions of pre-service teachers concerning assessment feedback. Data was collected by means of: (1) online questionnaires; (2) open-ended questions; and (3) focus group interviews with 108 participants. The findings highlighted that the teachers needed to trust their students, because a lack of academic trust can have a negative influence on feedback. A large-scale questionnaire study, conducted by Vasu et al. (2016), investigated 
107 university ESL students' perceptions of teacher feedback, peer feedback, and self-assessment in students' writing. The results indicated that the students perceived teacher feedback, self-assessment and peer feedback as being highly useful. A recent study by Zhan (2016) employed essays, questionnaires and interviews with a teacher and sixty-two Chinese students to examine the perceptions of both EFL students and teachers towards written teacher feedback. The findings revealed the presence of differences of perception between teacher and students, with students indicating that they wished for lengthier teacher feedback practices. A further recent study by Sharif and Zainuddin (2017) used a questionnaire to explore the perceptions of nineteen university ESL students concerning teacher feedback and its contribution to reflective writing. The findings indicated that the students found teacher feedback to be positive, beneficial, and encouraging.

Over the previous two decades, a number of studies have examined the value of feedback in learning, but only a limited number of these have focused specifically on exploring students' preferences towards different feedback types and strategies. A study conducted by Park (2010) investigated teachers' choice and students' preferences of corrective feedback. A questionnaire and a Test of English for International Communication (TOEIC) were used to collect data from twenty-four native English teachers and fifty-one EFL Korean university students. The results of the quantitative data indicated that teachers and students (of both high and low proficiency) preferred corrective feedback. A study conducted by Kaivanpanah et al. (2015) focused on: (1) examining EFL learners' preferences concerning different types of oral corrective feedback; (2) exploring the relationship between the feedback provided and learners' language proficiency; and (3) comparing the views of learners and teachers. Data was gathered by means of a thirty-six-item questionnaire applied to 154 EFL Iranian learners and twenty-five EFL teachers. Semi-structured interviews were also used to examine the opinions of the teachers in greater depth. The results reported that the more proficient learners preferred feedback requiring selfcorrection, while learners at all levels expressed more positive attitudes than their teachers towards peer and immediate feedback in relation to errors.

A growing body of up-to-date research has investigated both the perceptions and preferences of learners towards feedback. A study conducted by Sopin (2015) investigated the perceptions and preferences of ESL learners in Libyan secondary schools concerning the perceptions of corrective feedback of ESL learners. The results of a questionnaire administered to 120 students confirmed the positive value of corrective feedback. Moreover, evidence arising from the discussion reported that learners frequently felt offended or embarrassed (particularly in teacher-fronted classes) when corrective feedback was delivered in the presence of their peers. Furthermore, an exploratory study of Chen et al. (2016) investigated the perceptions and preferences of EFL learners towards written corrective feedback. Data was collected from sixty-four EFL Chinese learners, by means of a questionnaire containing both closed and open-ended questions. The results of the quantitative data revealed that EF learners demonstrated a favourable attitude towards error correction, with a strong preference for the provision of detailed comments on their written work. The results of the qualitative data indicated that EFL learners preferred to practice self-correction and revision of their writing, with less interference from their teachers. A recent study by Mungungu-Shipale and Kangira (2017) investigated the perceptions and preferences of tertiary lecturers and students in relation to the provision of corrective feedback on ESL speaking and writing skills in Namibian classrooms. The findings revealed that both university lecturers and students perceived teacher corrective feedback as an essential aspect of developing ESL speaking and writing skills.

Despite the importance of the above-reviewed studies, there remains a paucity of evidence concerning the perceptions of Saudi female EFL student teachers of the importance of teacher feedback practices, as well as their preferences for different types and delivery methods during their course project.

\section{Research Methodology}

This current study employed a mixed methods approach, including quantitative (closed questions) and qualitative (open-ended questions), to examine the perceptions and preferences of Saudi female EFL student teachers concerning teacher feedback in a PBL learning environment.

\subsection{Subjects}

The study initially recruited thirty-one postgraduate Saudi EFL student teachers, who were enrolled on the course 'Analysis of EFL Curriculum' during the second semester of the 2017 academic year. This course was selected due to one of its main learning outcomes and requirements being to conduct a project, which enabled the researcher to: (1) adapt the use of PBL; (2) implement different types and delivery methods of teacher feedback for the course project; and (3) track the participants' achievements and progress during the course of the project.

\subsection{Instruments}

Three questionnaires were used to collect data. The first questionnaire was devised by the researcher in response to the research objectives regarding EFL student teachers' perceptions of the importance of teacher feedback practices. The questionnaire was divided into two parts: In the first part, participants were asked a preliminary 
question regarding whether they believed feedback was important for their progress. The second part consisted of twenty 5-point Likert scale items aimed at identifying the participants' perceptions of teacher feedback. The items ranged from 'Totally disagree' to 'Totally agree' and were utilized based on a number of previously reviewed studies (Dargusch \& Davis, 2015; Grami, 2005; Vasu et al., 2016; Zhan, 2016).

The second questionnaire was also devised by the researcher to determine the participants' preferences for specific forms and delivery methods of teacher feedback. This was developed in response to the related literature (Chen et al., 2016; Park, 2010; Sopin, 2015), and was divided into two parts.

1. The first part was made up of two sections. The first section consisted of ten 5-point Likert scale items, which were specifically designed to cover the types of feedback provided during the course, i.e. descriptive; evaluative; motivational; corrective; and exploratory. The second section consisted of fourteen 5-point Likert scale items focusing on feedback delivery methods employed during the course, i.e. oral; written; immediate; formal; informal; group; and individual.

2. The second part consisted of an open-ended question focusing on the qualitative data. This provided space for Saudi female EFL student teachers to contribute their individual points of view, revealing a wide range of freely given responses concerning any further suggestions for future improvement of teacher feedback.

These new research instruments were sent to a panel of experts, in order to ensure their construct and content validity. The researcher undertook several rounds of drafting and revising, following which the experts' comments were considered and changes made in accordance with their suggestions. The experts suggested rewording some of the items to improve their clarity and readability. Some of changes recommended by the experts relating to specific types of feedback were also modified.

Finally, the instrument was administered to ten students, following which no further modifications were made, as the students confirmed the clarity of all the items. Moreover, Cronbach's alpha was run to measure the internal consistency of the items contained in both questionnaires. The results indicated high levels of internal consistency and reliability between the twenty items covering perceptions $(\alpha=0.923)$, and the twenty-four items covering preferences $(\alpha=0.705)$. These were higher values than the minimum accepted value of 0.70 .

The third questionnaire measured the levels of satisfaction of Saudi female EFL student teachers towards the course 'Analysis of EFL Curriculum'. The data was collected from the Course Evaluation University Questionnaire (CEUQ), i.e. an online unified questionnaire to indicate the quality of teaching for every university course, as a requirement by the Saudi National Commission for Academic Accreditation and Assessment (NCAAA). CEUQ covers four dimensions containing twenty-four 5-point Likert scale items. Additionally, it is generally administered online to all university students at the end of each semester in relation to all courses. Results of CEUQ are shown to instructors as an indicator of their quality of teaching.

\subsection{Procedures}

The researcher of the current study adapted PBL as a teaching method. As a student-centred pedagogy, PBL allows students to actively explore comprehensive knowledge and create authentic materials. Moreover, this approach develops skills for lifelong and cooperative learning. Furthermore, Eguchi and Eguchi (2006) noted that the use of PBL can: (1) empower students to set their learning goals: (2) enable them to work with others, by means of hands-on experiences in a meaningful environment; (3) increase self-confidence; (4) enhance motivation; and (5) reassign the teacher's role as a facilitator within a self-directed setting.

As a part of the course requirements (and based on the overall course objectives) the EFL student teachers were requested to carry out a course project. This required them to analyse and evaluate the EFL textbook for both semesters, as delivered to third year secondary school Saudi students, entitled 'Traveller 5 \& 6'. The student textbook known as 'Traveller' follows a modular approach and is organized into eight topic-based modules, each of which consists of two units.

Research on PBL primarily required identifying the stages of the project. Ravitz (2010) highlighted that, during the implementation of projects, it is vital to have: (1) extensive planning; (2) professional development; (3) a supportive environment; and (4) effective instructional strategies. Moss and Van Duzer (1998) concluded that the necessary stages of any project consist of: (1) the selection of topics; (2) making plans; (3) undertaking research; and (4) the sharing of results. More recently, Hüttel and Gnaur (2017) considered the following as constituting the phases of conducted projects: (1) the introduction to the topic; (2) methods; (3) group formation; (4) choice of topic; (5) project area formulation; and (5) evaluation of the project. Zancul et al. (2017) stated that project stages are set out as follows: (1) planning; (2) organization; (3) development; and (4) assessment. Based on the literature reviewed above, the researcher merged the stages of PBL with the phases of the provided types and delivery methods of teacher feedback. This formed the ten phases of the course delivery, as discussed below. 6.3.1. Phase 1: Planning the task

During the planning phase, the teacher considered giving students some control over the formation of teams and the choice of modules from the EFL textbook to analyse and evaluate. Also during this phase, the criteria 
to be used for assessment and regular meaningful feedback were clarified. Likewise, the course teacher drew up a detailed instruction sheet, which included the project requirement and assessment procedures, i.e. timing, types of assessment and criteria for assessment.

6.3.2. Phase 2: Providing resources

The participants downloaded the main materials for the course project: firstly, the EFL textbooks for Saudi Secondary School students 'Traveler (5 \& 6)'; secondly, the workbooks, and thirdly, the teacher's guide from iEn, the National Education Portal (https://ien.edu.sa). In addition, the teacher provided the students with a previously designed checklist for assessing EFL textbooks, covering the following ten dimensions: (1) textbook objectives; (2) organization and layout; (3) topics and sub-topics; (4) language skills; (5) aspects of language s; (6) exercises and activities; (7) teaching methods; (8) social \& cultural contexts; (9) supportive materials; and (10) practical considerations.

6.3.3. Phase 3: Clear instructions

The course teacher prepared, distributed, and discussed the detailed instruction sheet with the project teams, focusing on: (1) the required project report; (2) presentation slides; (3) final seminar demands; and (4) the criteria included in the project assessment sheet. All points were clearly explained orally during a one-hour meeting, in order to give the students an opportunity to discuss, ask, give comments, and suggest any modifications when it came to timing and grading. In addition, motivational feedback was provided to reduce students' anxiety relating to the course project. Moreover, oral exploratory feedback was provided to respond efficiently to participants' questions. Students were encouraged to use the same assessment criteria for both peer and self-assessment processes, and so become critical of their own work. During this phase, the course teacher approved the final makeup of the project teams. The eight modules that consisted of sixteen units in both textbooks (i.e. 'Traveler ( $5 \& 6)$ ') were distributed equally between the eight teams.

6.3.4. Phase 4: Initial work feedback

Following their introduction to the course project requirements (along with its instructions, materials and resources), the EFL student teachers commenced their analysis and evaluation processes, which resulted in questions and inquiries requiring teacher feedback. The teacher therefore assigned five days to address any questions, by means of the WhatsApp Messenger application. During these five days, they were given the opportunity to send parts of their initial work for immediate individual (and group) descriptive and written feedback.

6.3.5. Phase 5: Initial follow up session

During the fifth week of the project management, the EFL student teachers were assigned a two-hour on-site follow up session, during which they were given the opportunity to pose any hypothetical questions based on their current experience. The teacher answered their questions by means of immediate exploratory and evaluative feedback, as well as discussing any complex issues and reflected on their comments. In addition, she gave the students time to reflect on their own (or others') comments. The student teachers were asked to make notes of the main points and write down everyone's ideas. Towards the end of the discussion, the teacher summarized everything that had been covered, and concluded the session by giving oral, formal, and descriptive feedback for groups, by means of a short list of ideas for further improvement. As an alternative method, informal feedback was offered after each weekly class to individuals and/or groups.

6.3.6. Phase 6: First draft feedback

After the initial follow up session, the eight teams were ready to submit the first draft of their project report in order to obtain feedback. They were guided to submit their work and be prepared for any further comments. The teacher referred the formal notes to the leaders of the teams during the seventh week and provided them with written corrective feedback. Moreover, the teacher highlighted the areas in need of revision and improvement by providing written descriptive feedback.

6.3.7. Phase 7: Remedial follow up session

A remedial on-site follow up session was assigned during the tenth week. The teacher divided the class into eight separate sections, each focusing on for one team. Every team had prepared questions, comments and any related issues demanding a private discussion with the teacher. The teacher moved between teams, providing exploratory and corrective feedback by answering questions, discussing any comments, and writing down the general questions in her notes. Moreover, the teacher was shown the initial soft copy of the project report, allowing some of the comments to be immediately corrected. The teacher gave her final remarks orally towards the end of the remedial session, and which were based on her observation and written notes. Furthermore, the teams were provided with formal, group and immediate feedback at the close of this phase. The final report was then ready to be submitted to the course teacher for assessment. An opportunity for informal feedback was awarded to individuals and/or groups, following the remedial follow up session.

6.3.8. Phase 8: Project presentation

During the seminar, the EFL student teachers gave eight presentations, following the pre-arranged schedule consisting of the four modules of 'Traveler (5)', followed by the four modules of 'Traveler (6)'. The project 
teams used their analysis and evaluation to present the strengths, weaknesses, opportunities for improvement and the challenges facing the successful implementation of each module. Finally, the closing remarks were introduced, based on the team members' views and thoughts. In addition, the students were provided with frequent oral and motivational teacher feedback, in order to reduce their anxiety during this formal phase.

6.3.9. Phase 9: Reflection

As learning takes place by means of reflection, the teacher acted as a facilitator and helper to the EFL student teachers, enabling them to identify their own progress during the presentation. The teacher conducted formal rich discussions concerning the teams' experiences and personal views of the project. During the discussion, each team was given the chance to reflect on information included in the report regarding the analysis and evaluation of the modules. The teacher gave immediate, oral, evaluative and motivational feedback regarding their presentation in general, while the closing remarks overtly drew essential relationships and synthesized any new knowledge concerning teaching EFL in the Saudi context.

6.3.10. Phase 10: Project assessment

The assessment sheet was divided into two sections, with the first covering paperwork (i.e. the project report) and the second covering presentation skills. The teacher evaluated the efforts made to finalize the project report by following the instructions, correcting any mistakes, and taking note of comments, while also assessing the presentation section during the seminar held for all eight teams. The teacher discussed the scores with each team as they were given their results, including where they demonstrated satisfaction and comfort.

The project phases revealed that EFL student teachers were exposed to various different amounts and types of delivery methods of teacher feedback, in accordance with the needs of the course.

\section{Data Collection}

Following the completion of the project assessment, the questionnaires were submitted to the Saudi female EFL student teachers. The participants were informed that their responses would have no influence on their marks for the course itself, being only for research purposes, and treated as confidential.

\section{Data Analysis}

In order to answer the research questions, the collected data were analysed by means of SPSS Version 23, using the descriptive statistical method, including frequency, percentage, means, and standard deviations.

\section{Results}

In the closed response questions, the EFL student teachers were asked the following questions: (1) Did you receive feedback for you current 'Analysis of EFL Textbook' Project? and (2) Do you believe in the importance of feedback to your progress?. These two questions focused on obtaining overall positive or negative responses to the concept of the importance of receiving teacher feedback. The results revealed that all participants (i.e. $100 \%$ ) a reported positive response (i.e. 'yes') to both questions.

\subsection{Results of perceptions towards the importance of teacher feedback}

Frequencies, means and standard deviations were calculated in order to answer the first research question. The EFL student teachers were asked to rate their responses to the importance of teacher feedback on a 1-5 scale (see Table 1).

Table 1. EFL student teachers' perceptions of the importance of teacher feedback

\begin{tabular}{|c|c|c|c|c|c|c|c|c|}
\hline \multirow[b]{2}{*}{$\begin{array}{l}\text { Perceptions of teacher } \\
\text { feedback }\end{array}$} & \multicolumn{5}{|c|}{ The Scale } & \multirow[b]{2}{*}{ Mean } & \multirow[b]{2}{*}{ S.D. } & \multirow[b]{2}{*}{ Level } \\
\hline & $\begin{array}{l}\text { Totally } \\
\text { disagree }\end{array}$ & Disagree & Neutral & Agree & $\begin{array}{l}\text { Totally } \\
\text { agree }\end{array}$ & & & \\
\hline $\begin{array}{l}\text { 1. Improving the quality of } \\
\text { my work. }\end{array}$ & $\begin{array}{c}1 \\
(3.2)\end{array}$ & $\begin{array}{c}1 \\
(3.2)\end{array}$ & $\begin{array}{c}5 \\
(16.1)\end{array}$ & - & $\begin{array}{c}24 \\
(77.4)\end{array}$ & 4.61 & 0.92 & High \\
\hline $\begin{array}{l}\text { 2. Sharing experiences } \\
\text { among classmates. }\end{array}$ & $\begin{array}{c}1 \\
(3.2)\end{array}$ & $\begin{array}{c}1 \\
(3.2)\end{array}$ & $\begin{array}{c}1 \\
(3.2)\end{array}$ & $\begin{array}{c}14 \\
(45.2)\end{array}$ & $\begin{array}{c}14 \\
(45.2)\end{array}$ & 4.26 & 0.93 & High \\
\hline $\begin{array}{l}\text { 3. Expanding my learning } \\
\text { beyond the project content. }\end{array}$ & - & $\begin{array}{c}2 \\
(6.5)\end{array}$ & $\begin{array}{c}5 \\
(16.1)\end{array}$ & $\begin{array}{c}14 \\
(45.2)\end{array}$ & $\begin{array}{c}10 \\
(32.3)\end{array}$ & 4.03 & 0.87 & Moderate \\
\hline $\begin{array}{l}\text { 4. Focusing on how to tie } \\
\text { project components together. }\end{array}$ & - & $\begin{array}{c}2 \\
(6.5)\end{array}$ & $\begin{array}{c}2 \\
(6.5)\end{array}$ & $\begin{array}{c}13 \\
(41.9)\end{array}$ & $\begin{array}{c}14 \\
(45.2)\end{array}$ & 4.26 & 0.86 & High \\
\hline $\begin{array}{l}\text { 5. Offering additional } \\
\text { valuable information to the } \\
\text { existing tasks. }\end{array}$ & - & $\begin{array}{c}2 \\
(6.5)\end{array}$ & $\begin{array}{c}3 \\
(9.7)\end{array}$ & $\begin{array}{c}14 \\
(45.2)\end{array}$ & $\begin{array}{c}12 \\
(38.7)\end{array}$ & 4.16 & 0.86 & Moderate \\
\hline $\begin{array}{l}\text { 6. Posing questions to } \\
\text { obtain more information. }\end{array}$ & - & $\begin{array}{c}2 \\
(6.5)\end{array}$ & $\begin{array}{c}2 \\
(6.5)\end{array}$ & $\begin{array}{c}17 \\
(54.8)\end{array}$ & $\begin{array}{c}10 \\
(32.3)\end{array}$ & 4.13 & 0.81 & Moderate \\
\hline
\end{tabular}




\begin{tabular}{|c|c|c|c|c|c|c|c|c|}
\hline $\begin{array}{l}\text { 7. Meeting my individual } \\
\text { needs for specific guidance. }\end{array}$ & $\begin{array}{c}1 \\
(3.2)\end{array}$ & $\begin{array}{c}2 \\
(6.5)\end{array}$ & $\begin{array}{c}1 \\
(3.2)\end{array}$ & $\begin{array}{c}16 \\
(51.6)\end{array}$ & $\begin{array}{c}11 \\
(35.5)\end{array}$ & 4.10 & 0.98 & Moderate \\
\hline $\begin{array}{l}\text { 8. Increasing my self- } \\
\text { confidence. }\end{array}$ & $\begin{array}{c}1 \\
(3.2)\end{array}$ & $\begin{array}{c}1 \\
(3.2)\end{array}$ & $\begin{array}{c}1 \\
(3.2)\end{array}$ & $\begin{array}{c}12 \\
(38.7)\end{array}$ & $\begin{array}{c}16 \\
(51.6)\end{array}$ & 4.32 & 0.94 & High \\
\hline $\begin{array}{l}\text { 9. Providing me with } \\
\text { opportunities for future self- } \\
\text { learning. }\end{array}$ & - & $\begin{array}{c}1 \\
(3.2)\end{array}$ & $\begin{array}{c}2 \\
(6.5)\end{array}$ & $\begin{array}{c}14 \\
(45.2)\end{array}$ & $\begin{array}{c}14 \\
(45.2)\end{array}$ & 4.32 & 0.75 & High \\
\hline $\begin{array}{l}\text { 10. Keeping me on target for } \\
\text { finishing the task. }\end{array}$ & $\begin{array}{c}2 \\
(6.5)\end{array}$ & - & - & $\begin{array}{c}16 \\
(51.6)\end{array}$ & $\begin{array}{c}13 \\
(41.9)\end{array}$ & 4.23 & 0.99 & High \\
\hline $\begin{array}{l}\text { 11. Training me to give } \\
\text { feedback to other classmates. }\end{array}$ & $\begin{array}{c}3 \\
(9.7)\end{array}$ & - & $\begin{array}{c}3 \\
(9.7)\end{array}$ & $\begin{array}{c}13 \\
(41.9)\end{array}$ & $\begin{array}{c}12 \\
(38.7)\end{array}$ & 4.10 & 0.94 & Moderate \\
\hline $\begin{array}{l}\text { 12. Organizing my thoughts } \\
\text { while working on the } \\
\text { project. }\end{array}$ & $\begin{array}{c}1 \\
(3.2)\end{array}$ & - & $\begin{array}{c}1 \\
(3.2)\end{array}$ & $\begin{array}{c}9 \\
(29.0)\end{array}$ & $\begin{array}{c}20 \\
(64.5)\end{array}$ & 4.52 & 0.85 & High \\
\hline $\begin{array}{l}\text { 13. Discussing my personal } \\
\text { opinions and views. }\end{array}$ & - & $\begin{array}{c}4 \\
(12.9)\end{array}$ & $\begin{array}{c}3 \\
(9.7)\end{array}$ & $\begin{array}{c}12 \\
(38.7)\end{array}$ & $\begin{array}{c}12 \\
(38.7)\end{array}$ & 4.03 & 1.02 & Moderate \\
\hline $\begin{array}{l}\text { 14. Dealing with low } \\
\text { performance constructively. }\end{array}$ & - & $\begin{array}{c}4 \\
(12.9)\end{array}$ & $\begin{array}{c}1 \\
(3.2)\end{array}$ & $\begin{array}{c}15 \\
(48.4)\end{array}$ & $\begin{array}{c}11 \\
(35.5)\end{array}$ & 4.06 & 0.96 & Moderate \\
\hline $\begin{array}{l}\text { 15. Inspiring me to develop } \\
\text { my performance to a higher } \\
\text { level. }\end{array}$ & - & $\begin{array}{c}1 \\
(3.2)\end{array}$ & $\begin{array}{c}3 \\
(9.7)\end{array}$ & $\begin{array}{c}11 \\
(35.5)\end{array}$ & $\begin{array}{c}16 \\
(51.6)\end{array}$ & 4.35 & 0.80 & High \\
\hline $\begin{array}{l}\text { 16. Enabling me to } \\
\text { understand my strengths and } \\
\text { weaknesses. }\end{array}$ & $\begin{array}{c}1 \\
(3.2)\end{array}$ & $\begin{array}{c}1 \\
(3.2)\end{array}$ & $\begin{array}{c}3 \\
(9.7)\end{array}$ & $\begin{array}{c}11 \\
(35.5)\end{array}$ & $\begin{array}{c}15 \\
(48.4)\end{array}$ & 4.23 & 0.99 & High \\
\hline $\begin{array}{l}\text { 17. Creating opportunities for } \\
\text { in-class and in-groups } \\
\text { discussion. }\end{array}$ & $\begin{array}{c}1 \\
(3.2)\end{array}$ & $\begin{array}{c}3 \\
(9.7)\end{array}$ & $\begin{array}{c}3 \\
(9.7)\end{array}$ & $\begin{array}{c}10 \\
(32.3)\end{array}$ & $\begin{array}{c}14 \\
(45.2)\end{array}$ & 4.06 & 1.12 & Moderate \\
\hline $\begin{array}{l}\text { 18. Providing opportunities } \\
\text { to reflect on my own } \\
\text { learning. }\end{array}$ & $\begin{array}{c}1 \\
(3.2)\end{array}$ & $\begin{array}{c}1 \\
(3.2)\end{array}$ & $\begin{array}{c}3 \\
(9.7)\end{array}$ & $\begin{array}{c}13 \\
(41.9)\end{array}$ & $\begin{array}{c}13 \\
(41.9)\end{array}$ & 4.16 & 0.97 & Moderate \\
\hline $\begin{array}{l}\text { 19. Enhancing my motivation } \\
\text { to learn. }\end{array}$ & - & $\begin{array}{c}3 \\
(9.7) \\
\end{array}$ & $\begin{array}{c}2 \\
(6.5) \\
\end{array}$ & $\begin{array}{c}13 \\
(41.9)\end{array}$ & $\begin{array}{c}13 \\
(41.9) \\
\end{array}$ & 4.16 & 0.93 & Moderate \\
\hline $\begin{array}{l}\text { 20. Decreasing anxiety about } \\
\text { losing grades in the project. }\end{array}$ & $\begin{array}{c}1 \\
(3.2)\end{array}$ & $\begin{array}{c}4 \\
(12.9)\end{array}$ & $\begin{array}{c}4 \\
(12.9)\end{array}$ & $\begin{array}{c}9 \\
(29.0)\end{array}$ & $\begin{array}{c}13 \\
(41.9)\end{array}$ & 3.94 & 1.18 & Moderate \\
\hline
\end{tabular}

The results shown in Table 1 reveal that the responses of the Saudi female EFL student teachers' to nine items indicate complete agreement in their perceptions towards the importance of teacher feedback. Almost twenty-four $(77.4 \%)$ of the EFL student teachers (item 1, M=4.61) totally agreed that teacher feedback improved the quality of their work. Similarly, twenty (64.5\%) (item 12, M=4.52) completely agreed that teacher feedback enabled them to organize their thoughts while working on course project. The results also revealed that sixteen $(51.6 \%)$ of the participants with average mean value (item 15, M=4.35) completely agreed that the feedback from their teacher inspired them to develop their performance to a higher level. Moreover, the results reveal two equal mean scores (items $8 \& 9, \mathrm{M}=4.32$ ) with two different numbers of responses (i.e. sixteen $(51.6 \%)$ and fourteen $(45.2 \%)$, respectively), both of which indicate the high value placed on teacher feedback for increasing self-confidence and providing opportunities for future self-learning.

Likewise, the results show that EFL student teachers responded equally when it comes to mean scores (items $2 \& 4, M=4.26$ ) and numbers (fourteen (45.2\%)), while also indicating their complete agreement with the statement that teacher feedback enabled them to share experiences with their classmates and directed their focus towards how to tie the project components together. In addition, the results reveal that two equal mean scores (items $16 \& 10, \mathrm{M}=4.23)$, with two different number of responses of fifteen $(48.4 \%)$ and thirteen $(41.9 \%)$, respectively, resulted in a high-level response. In both responses, EFL student teachers pointed out their complete agreement with the statement that teacher feedback enabled them to understand their strengths and weaknesses, while at the same time keeping them on target to finish the task.

Furthermore, the results demonstrated in Table 1 indicate that over half of those surveyed reported a fairly strong agreement in having moderate level of positive perceptions towards the importance of teacher feedback. Further results showed that fourteen $(45.2 \%)$ of the respondents (items $5 \mathrm{M}=4.16)$ fairly strongly agreed that teacher feedback offers additional valuable information concerning the existing tasks. In addition, items eighteen and nineteen indicate a similar number of responses (i.e. thirteen $(41.9 \%)$ ) with identical mean scores $(\mathrm{M}=4.16)$, identifying that the EFL student teachers were in complete agreement that teacher feedback provides an 
opportunity to reflect on learning, while at the same time enhancing students' motivation to learn.

The results reveal that over half of those surveyed (i.e. seventeen $(54.8 \%)$ ) with a mean score (i.e. item 6 $\mathrm{M}=4.13$ ) valued teacher feedback as a source of information when posing questions. TWO statements indicated the same mean score (items 7 and $11 \mathrm{M}=4.10)$, with two different frequencies, sixteen $(51.6 \%)$ and thirteen $(41.9 \%)$, respectively. In both responses, the participants agreed moderately that teacher feedback met their individual need for guidance, while also training them to give feedback to their classmates. Furthermore, the results reveal that fifteen $(48.4 \%)$ of the EFL student teachers responded moderately (items $14 \mathrm{M}=4.06$ ) that teacher feedback enabled them to deal with their low performance in a constructive manner. In addition, fourteen $(45.2 \%)$ of the respondents with a mean score (items $17 \mathrm{M}=4.06)$ agreed moderately that teacher feedback created opportunities for in-class and in-groups discussion.

The mean score $(\mathrm{M}=4.03)$ of item 3 represents a moderate agreement among fourteen $(45.2 \%)$ of the participants that teacher feedback expands learning beyond the project content. Furthermore, the results show that twelve (38.7\%) of the EFL student teachers with mean scores (items 13, M=4.03) agreed moderately that teacher feedback focuses attention on the discussion of personal opinions and views. Finally, thirteen (41.9\%) of the participants agreed completely and moderately (item 20, M=3.94) that teacher feedback decreases anxiety about the project resulting in a loss of grades.

\subsection{Results of EFL student teachers' preferences of types of teacher feedback}

In the questionnaire employed to gather the data, the participants were provided with the types and delivery methods of teacher feedback, along with an explanation of how this could be used in a classroom situation. In order to answer the second research question, the average mean of the EFL student teachers' preferences of types of teacher feedback was employed to identify the appropriate mean range. The results are presented in Table 2. Table 2. EFL student teachers' preferences of types of teacher feedback

\begin{tabular}{|c|c|c|c|c|c|c|}
\hline \multirow{2}{*}{$\begin{array}{l}\text { Teacher } \\
\text { feedback } \\
\text { types }\end{array}$} & \multirow{2}{*}{ Preferences questionnaire items } & \multicolumn{2}{|c|}{$\begin{array}{c}\text { Scores for each } \\
\text { item }\end{array}$} & \multicolumn{2}{|c|}{$\begin{array}{l}\text { Scores of both } \\
\text { items }\end{array}$} & \multirow{2}{*}{ Level } \\
\hline & & Mean & S.D. & Mean & S.D. & \\
\hline \multirow{2}{*}{$\begin{array}{l}\text { Descriptive } \\
\text { Feedback }\end{array}$} & $\begin{array}{l}\text { 1. I learn more when feedback describes the areas } \\
\text { which need to be improved. }\end{array}$ & 4.68 & 0.54 & \multirow{2}{*}{4.68} & \multirow{2}{*}{0.54} & \multirow{2}{*}{ High } \\
\hline & $\begin{array}{l}\text { 2. I move forward in my learning process based } \\
\text { on the descriptive feedback. }\end{array}$ & 4.68 & 0.54 & & & \\
\hline \multirow[b]{2}{*}{$\begin{array}{l}\text { Evaluative } \\
\text { Feedback }\end{array}$} & $\begin{array}{l}\text { 3. I can manage necessary feedback for giving a } \\
\text { score or a grade. }\end{array}$ & 4.06 & 0.96 & \multirow[b]{2}{*}{2.51} & \multirow[b]{2}{*}{1.89} & \multirow[b]{2}{*}{ Low } \\
\hline & $\begin{array}{l}\text { 4. I prefer evaluative feedback that summarizes } \\
\text { my achievement without providing future } \\
\text { guidance. }\end{array}$ & 2.52 & 1.26 & & & \\
\hline \multirow{2}{*}{$\begin{array}{l}\text { Motivational } \\
\text { feedback }\end{array}$} & $\begin{array}{l}\text { 5. It would be supportive for my learning to } \\
\text { receive motivational feedback. }\end{array}$ & 4.77 & 0.43 & \multirow{2}{*}{4.48} & \multirow{2}{*}{0.83} & \multirow{2}{*}{ High } \\
\hline & $\begin{array}{l}\text { 6. Receiving feedback that reduces my anxiety is } \\
\text { preferable. }\end{array}$ & 4.19 & 1.22 & & & \\
\hline \multirow{2}{*}{$\begin{array}{l}\text { Corrective } \\
\text { feedback }\end{array}$} & $\begin{array}{l}\text { 7. I can easily manage my learning when } \\
\text { receiving corrective feedback. }\end{array}$ & 4.58 & 0.62 & \multirow{2}{*}{4.58} & \multirow{2}{*}{0.59} & \multirow{2}{*}{ High } \\
\hline & $\begin{array}{l}\text { 8. Corrective feedback decreases the amount of } \\
\text { time spent in tracking mistakes and errors. }\end{array}$ & 4.58 & 0.56 & & & \\
\hline \multirow{2}{*}{$\begin{array}{l}\text { Exploratory } \\
\text { Feedback }\end{array}$} & $\begin{array}{l}\text { 9. Feedback based on exploratory questions } \\
\text { inspires me to think differently of my work. }\end{array}$ & 4.26 & 0.73 & \multirow{2}{*}{4.33} & \multirow{2}{*}{0.70} & \multirow{2}{*}{ High } \\
\hline & $\begin{array}{l}\text { 10. Providing feedback by posing questions } \\
\text { takes my comprehension to a deeper level. }\end{array}$ & 4.39 & 0.67 & & & \\
\hline
\end{tabular}

Table 2 demonstrates the EFL student teachers' preferences for specific types of teacher feedback, and that these tend to be positive. Of the five types of teacher feedback provided for the course project, the highest means were registered for the following types: (1) descriptive; (2) corrective; (3) motivational; and (4) exploratory teacher feedback with average mean scores $(\mathrm{M}=4.68,4.58,4.48,4.33)$, respectively. The low level of agreement and preference $(\mathrm{M}=2.51)$ indicated by the participants falls concerns evaluative teacher feedback.

\subsection{Results of EFL student teachers' preferences of delivery methods of teacher feedback}

In order to answer the third research question, the responses of the Saudi female EFL student teachers concerning preferences towards the delivery methods of teacher feedback are summarized in Table 3 . The columns show the average means and the levels of preferences towards the methods of teacher feedback. The 
participants rated each statement in accordance with the five-point Likert scale.

Table 3. EFL student teachers' preferences of methods of teacher feedback delivery

\begin{tabular}{|c|c|c|c|c|c|c|}
\hline \multirow{2}{*}{$\begin{array}{l}\text { Teacher } \\
\text { feedback } \\
\text { methods }\end{array}$} & \multirow{2}{*}{ Preferences questionnaire items } & \multicolumn{2}{|c|}{$\begin{array}{l}\text { Scores for each } \\
\text { item }\end{array}$} & \multicolumn{2}{|c|}{$\begin{array}{l}\text { Scores of both } \\
\text { items }\end{array}$} & \multirow{2}{*}{ Level } \\
\hline & & Mean & S.D. & Mean & S.D. & \\
\hline \multirow{2}{*}{ Oral feedback } & $\begin{array}{l}\text { 1. Feedback seems beneficial when provided } \\
\text { orally. }\end{array}$ & 3.84 & 1.37 & \multirow{2}{*}{3.99} & \multirow{2}{*}{1.23} & \multirow{2}{*}{ Moderate } \\
\hline & $\begin{array}{l}\text { 2. Oral feedback allows for deep in-class } \\
\text { interaction. }\end{array}$ & 4.13 & 1.09 & & & \\
\hline \multirow{2}{*}{$\begin{array}{l}\text { Written } \\
\text { feedback }\end{array}$} & $\begin{array}{l}\text { 3. I could develop my skills in the best } \\
\text { possible way when receiving written } \\
\text { feedback. }\end{array}$ & 3.90 & 1.19 & \multirow[t]{2}{*}{4.02} & \multirow[t]{2}{*}{1.16} & \multirow[t]{2}{*}{ Moderate } \\
\hline & $\begin{array}{l}\text { 4. Written feedback makes it easy to track } \\
\text { my mistakes. }\end{array}$ & 4.13 & 1.12 & & & \\
\hline \multirow{2}{*}{$\begin{array}{l}\text { Immediate } \\
\text { feedback }\end{array}$} & $\begin{array}{l}\text { 5. Immediate feedback gives a progressively } \\
\text { decreasing score for multiple attempts. }\end{array}$ & 4.26 & 0.77 & \multirow{2}{*}{4.4} & \multirow{2}{*}{0.9} & \multirow{2}{*}{ High } \\
\hline & $\begin{array}{l}\text { 6. I usually find immediate feedback } \\
\text { productive to my learning experience. }\end{array}$ & 4.35 & 0.98 & & & \\
\hline \multirow{2}{*}{$\begin{array}{l}\text { Informal } \\
\text { Feedback }\end{array}$} & $\begin{array}{l}\text { 7. I completely engage in task improvement } \\
\text { when only occasionally receiving feedback. }\end{array}$ & 4.26 & 0.89 & \multirow{2}{*}{4.3} & \multirow{2}{*}{1.0} & \multirow{2}{*}{ High } \\
\hline & $\begin{array}{l}\text { 8. I prefer to be provided with feedback from } \\
\text { my teacher whenever it is needed. }\end{array}$ & 4.29 & 1.07 & & & \\
\hline \multirow{2}{*}{$\begin{array}{l}\text { Formal } \\
\text { feedback }\end{array}$} & $\begin{array}{l}\text { 9. Feedback is beneficial when provided } \\
\text { through planned meetings. }\end{array}$ & 3.13 & 1.26 & \multirow{2}{*}{3.5} & \multirow{2}{*}{1.3} & \multirow{2}{*}{ Moderate } \\
\hline & $\begin{array}{l}10 . \quad \text { Receiving feedback that focuses on } \\
\text { individualized goals is developmental. }\end{array}$ & 3.81 & 1.28 & & & \\
\hline \multirow[t]{2}{*}{ Group feedback } & $\begin{array}{l}11 . \quad \text { Group feedback involves me in a } \\
\text { supportive and communicative learning } \\
\text { atmosphere. }\end{array}$ & 4.23 & 0.88 & \multirow[t]{2}{*}{4.3} & \multirow[t]{2}{*}{0.8} & \multirow[t]{2}{*}{ High } \\
\hline & $\begin{array}{l}\text { 12. Through group feedback, different } \\
\text { learning skills are covered. }\end{array}$ & 4.39 & 0.76 & & & \\
\hline \multirow{2}{*}{$\begin{array}{l}\text { Individual } \\
\text { feedback }\end{array}$} & $\begin{array}{l}13 . \quad \text { Receiving individual feedback } \\
\text { promotes me to think more deeply about my } \\
\text { work. }\end{array}$ & 4.32 & 0.83 & \multirow{2}{*}{4.3} & \multirow{2}{*}{0.8} & \multirow{2}{*}{ High } \\
\hline & $\begin{array}{l}14 . \quad \text { Providing individual feedback } \\
\text { inspires me to put a focused effort into my } \\
\text { work. }\end{array}$ & 4.26 & 0.82 & & & \\
\hline
\end{tabular}

Table 3 demonstrates that the EFL student teachers' preferences concerning the delivery methods of teacher feedback was highly rated. Among the seven delivery methods of teacher feedback, the participants revealed a high level of preference for immediate teacher feedback, with an average mean score of $M=4.4$. Likewise, they highly rated informal, group, and individual teacher feedback, with equal average mean scores $(\mathrm{M}=4.3)$. Written, oral, and formal teacher feedback were rated at a moderate level of preference, with average mean scores $(\mathrm{M}=4.02,3.99,3.5)$.

\subsection{Results of the open-ended question}

In response to the open-ended question 'Do you have any concerns or suggestions regarding the use of teacher feedback?', approximately $74.19 \%$ of the EFL student teachers indicated that they recognized the value and importance of teacher feedback. They also understood that the feedback they were given during their course projects was intended to also be of benefit to their subsequent assignments and courses (twenty-three responses). Almost six responses (i.e. 19.35\%) stated a need to specify at least two fixed meetings for each course, for the exclusive purpose of receiving teacher feedback on assignments, tests, activities or projects.

At the same time, four of the participants $(12.90 \%)$ considered it beneficial to use frequent teacher feedback in each lecture to provide the most effective assistance to learners. Furthermore, one participant (3.23\%) stated that "feedback should be given to the final draft of the project not only the initial drafts". Almost five participants (16.13\%) reported the importance of using different and varied types of teacher feedback. Likewise, three responses (i.e. 9.68\%) recommended the use of different and various delivery methods of feedback. Two (i.e. $6.45 \%$ ) EFL student teachers complained of receiving frequent oral feedback, i.e. the non-preferred method 
of teacher feedback, while four (12.90\%) requested additional written teacher feedback on their work. Finally, two EFL student teachers $(6.45 \%)$ tied the effectiveness of feedback practices to more opportunities to ask questions, share information, and discuss issues with their teacher and peers.

\subsection{Results of EFL student teachers' satisfaction}

Table 4 summarizes the responses of EFL student teachers in relation to CEUQ regarding their satisfaction with different areas of the course (see Appendix A). The results indicate a highly positive overall response to the questionnaire items, with high levels of satisfaction.

Table 4. EFL student teachers' satisfaction with their course

\begin{tabular}{|c|c|c|c|c|}
\hline \multirow{2}{*}{ Dimensions } & \multicolumn{3}{|c|}{ Average } & \multirow{2}{*}{ Level } \\
\hline & $\%$ & Mean & S.D. & \\
\hline 1. Beginning of the Course & 93.54 & 4.93 & 0.30 & High \\
\hline 2. Implementation of the Course & 84.48 & 4.77 & 0.56 & High \\
\hline 3. Course Content Evaluation & 73.39 & 4.57 & 0.79 & High \\
\hline 4. Students' General Satisfaction & 80.65 & 4.81 & 0.40 & High \\
\hline
\end{tabular}

In general, almost $93.54 \%$ of the Saudi female EFL student teachers reported that they were satisfied with the beginning of the course (items 1 to 3), with an average mean score $(\mathrm{M}=4.93, \mathrm{SD}=0.30)$. They noted that the basic lines, and requirements for success were clarified, along with the course resources and references.

Similarly, $84.48 \%$ of the participants strongly agreed and stated being highly satisfied with the implementation of the course (items 4 to 19), with an average mean score $(\mathrm{M}=4.77, \mathrm{SD}=0.56)$. They indicated their satisfaction with the following: (1) the knowledge provided; (2) the consistency of requirements concerning the course content; (3) the fairness of assignments and correction of tests; (4) teacher enthusiasm and encouragement; (5) reasonable time given for submitting the grades; and (6) the effective use of technology in the classroom. Moreover, the participants strongly agreed, and stated being highly satisfied, with: (1) the teacher's commitment; (2) the provision of useful and up-to-date materials; (3) availability of course resources; and (4) the effectiveness of course requirements in relation to course knowledge and skills. In addition, they reported their high level of satisfaction with the appropriateness of amount of work required for the course credit hours, and the clarity of the relationship between this course and other courses in the EDP.

When it came to the participants' satisfaction with the evaluation of the course content (items 20 to 23), the results shown in Table 4 indicate a strong agreement of $73.39 \%$ of the respondents with high level of satisfaction and average mean score $(\mathrm{M}=4.57, \mathrm{SD}=0.79)$. EFL student teachers reported that they felt satisfied with their personal improvement when it came to communication, teamwork, and problem-solving skills, as well as the benefits of learned information for their future career. It can be generally observed from the data in Table 4 that $80.65 \%$ of EFL student teachers with an average mean score $(\mathrm{M}=4.81, \mathrm{SD}=0.40)$ reported their overall high level of satisfaction with the quality of the course.

\section{Discussion of the findings}

Overall, the findings revealed moderate to high positive perceptions and preferences towards teacher feedback. The findings relating to the students' perceptions demonstrated that they had a strong desire to receive feedback from their teacher, and found this beneficial to the improvement of their work. They also demonstrated positive perceptions towards the importance of teacher feedback practices. These findings accord with the results of studies carried out by Carless (2006), Dargusch and Davis (2015), Grami (2005), Hewitt (2008), Westwood (2008), and Zhan (2016), who reported that students preferred teacher feedback that supported the quality of their work in a positive manner, including informing them of the most important actions they needed to take in order to ensure further improvement.

These findings are also in line with Sharif and Zainuddin (2017), who identified teacher feedback as being encouraging, as well as Susanti (2013), who considered that teacher feedback increases the learning autonomy of students. Furthermore, the results are also in accord with the studies conducted by Nuramirah (2017), Rowe and Wood (2008), Vasu et al. (2016), and Zacharias (2007). These viewed teacher feedback as a valuable resource, which acts to reduce students' anxiety, while at the same time providing them with comprehensible input and output, vital comments, and further opportunities for self-assessment.

The teacher's feedback, along with the project observation, revealed that positive perceptions can arise in response to effective planning on the part of the teacher, in particular that designed to give students greater control over their learning by allowing them to become actively involved in the different phases of the project. These tactics left sufficient space for EFL student teachers to act independently, including to: (1) explore new knowledge; (2) construct questions; (3) request frequent feedback from the teacher; and (4) share ideas and expertise with peers. As noted by Bas (2011), Hasani et al. (2017), Hixson et al. (2012), Şat (2013), Simpson (2011), Ravitz (2010), and Wrigley (1998), PBL (being as a cooperative-centred learning method) contains a number of features capable of benefitting learning, including: (1) emphasizing the depth of learning and intrinsic 
motivation; (2) developing innovative ideas; and (3) building vital skills.

The findings revealed that the EFL student teachers demonstrated a positive preference for all types and delivery methods of teacher feedback implemented in the current study. This may be due to the planned phases of the course, during which there was frequent provision of different types of teacher feedback by means of a variety of delivery methods. These results align with those of Kahraman and Yalvaç (2015) and Sharif and Zainuddin (2017), who claimed that learners generally tend to indicate a strong need for different types of teacher feedback, even if provided on an infrequent basis, or accompanied by insufficient comments.

When it came to the different types of teacher feedback, the findings revealed that EFL student teachers preferred the provision of descriptive, corrective, motivational, and exploratory feedback during the different phases of their course. These results accord with a substantial body of research undertaken by the following: Abad et al. (2013); Chen et al. (2016); Defalco et al. (2014); Jodaie (2014); Kahraman and Yalvaç (2015); Lipnevich and Smith (2009); Mungungu-Shipale and Kangira (2017); and Sopin (2015). These studies identified that detailed teacher feedback was effective, preferable, and had a positive impact on the enhancement of performance and engagement with learning. The findings revealed that the students showed least preference towards evaluative feedback. This outcome agrees with Hattie and Timperley (2007), who concluded that unclear evaluative feedback leads to poor performance and results in a substandard self-image.

Furthermore, the findings revealed a high level of preference for immediate, informal, group, and individual teacher feedback. This could arise from the frequent, immediate, individual, and group feedback provided during the different phases of the course project. These findings correspond with a number of previous studies, including: Douglas et al. (2016); Ferguson (2011); Kaivanpanah et al. (2015); Rowe and Wood (2008); and Şeker and Sezgin (2013). These researchers concluded that many students viewed the different methods of teacher feedback as reducing their levels of anxiety, as well as providing effective, relevant, and appropriate comments. Furthermore, the results revealed that the least positive preferences related to oral, written, and formal teacher feedback. These findings disagree with those obtained by the following: Carless (2006); Fakeye (2016); González (2010); Grami (2005); Jodaie (2014); Kaur and Singh (2016); Park (2010); Rahimi (2010); and Susanti (2013). These studies reported that both teachers and learners: (1) highlighted the need for additional oral and written teacher feedback, as this provides individualized, text-based and contextualized instruction and (2) noted that students take seriously, and pay more attention to, feedback that is formal, oral and written.

The current researcher concluded that the participants of this present study indicated lower levels of preference (i.e. in comparison to other deliver methods) for oral, written, and formal feedback, due to due to its negative impact. These methods can reduce the motivation of students, particularly if the comments are general, unclear, and/or unsatisfying. It is also clear that the students preferred regular one-to-one meetings with their teacher, during which they were exposed to formal, oral and/or written feedback, along with sufficient opportunities for discussion and questioning. This interpretation is confirmed by the participants' responses to the qualitative data, i.e. $12.90 \%$ requested additional written feedback on their work. Furthermore, this result is supported by Zhan (2016), who reported that students indicated their wish for additional teacher feedback.

The data obtained from CEUQ confirmed a high level of student satisfaction concerning the course in general, including its content, implementation and evaluation. An additional reason may be due to the course being delivered using PBL as a constructivist-based method, i.e. one that provides opportunities for learners to guide, manage and monitor their learning. Furthermore, it respects learners' ability to select desired tasks and encourages their productive abilities. This interpretation is supported by the reviewed literature of Grant (2011); Hixson et al. (2012); Hüttel and Gnaur (2017); Pieratt (2010); and Tamba et al. (2017). EFL student teachers appeared to value the PBL method in response to its encouragement of deep learning. This finding aligns with that of Simpson (2011), who claimed that teachers can motivate and assist learners to fully engage in deep learning when they give them the opportunity to question, imagine, and challenge each other.

A further reason for the level of satisfaction with the course could result from the careful planning and flexibility on the part of the teacher during the ten phases, during which her role as a facilitator of the learning process, as well as a guide and a resource provider proved effective. This interpretation is supported by the findings of Moss and Van Duzer (1998). Furthermore, the students were given opportunities to fulfil their roles within the PBL environment, including being guided to: (1) draw up their plans; (2) negotiate ideas; (3) collaborate with team members; (4) reflect on their knowledge; and (5) self-regulate their learning skills. This interpretation is supported by the reviewed literature of Grant (2011), Moss and Van Duzer (1998), Solomon (2003), and Thomas (2000), who recommended that learners in a PBL setting should be directed to: (1) detect problems; (2) find solutions; (3) show full responsibility; (4) gather information; and (5) finalize products.

Moreover, the highly positive responses to the open-ended question confirm the satisfaction results when the EFL student teachers valued teacher feedback on their course projects. In addition, they expressed confidence in the frequent use of teacher feedback in each lecture providing the highest level of assistance and thus completely satisfying the needs of learners. 


\section{Conclusion and recommendations}

The current study focused on serving as a first step in identifying the perceptions of Saudi female EFL student teachers towards firstly, the importance of teacher feedback practices and secondly, their preferences for different types and delivery methods during their course project. This was also seen as the initial stage of improving the feedback process of higher education institutions. The data for the study were gathered from thirty-one Saudi EFL student teachers studying at EDP and employed three 5-point Likert scale questionnaires. The results focused on establishing valuable insights into students' perceptions and preferences regarding the nature of types and delivery methods of teacher feedback, along with an ability to express their satisfaction with the course delivery in general.

The results revealed that the EFL student teachers who were taught the course 'Analysis of the EFL Curriculum' through PBL, while being given different delivery methods of teacher feedback, demonstrated moderate to high positive perceptions and preferences. Moreover, they recognized the value and importance of these feedback practices to benefit their subsequent assignments and courses. The students therefore expressed their wish for additional planned meetings to receive their teachers' feedback on assignments, tests, activities or projects. Likewise, the EFL student teachers expressed their interest in having additional written feedback on their work, as well as further opportunities to ask questions, share information, and discuss issues with the teacher and their peers. Thus, the different types and delivery methods of teacher feedback were generally found to be effective and to be of considerable value to learners.

The research results stress that the use of different types and delivery methods of teacher feedback as a consistent aspect of the classroom has a number of advantages for EFL student teachers. Firstly, the implementation of teacher feedback practices encourages the creation of cooperative and communitive language learning settings, in which learners gain opportunities to negotiate, interact, discuss and improve their work.

Secondly, the use of a mixture of PBL and different teacher feedback practices emphasizes the depth of learning and increases intrinsic motivation as key benefits of PBL. An adaption of this mixture during the phases of a project can thus encourage learners to: (1) support each other; (2) increase their engagement with the learning process; (3) create a strong bond with team members; and (4) recognize their own strengths and weaknesses.

Thirdly, the provision of sufficient high quality teacher feedback by means of an effective medium: (1) encourages both self- and peer-correction; (2) matches learners' various needs, expectations, and attitudes; (3) builds up learners' sense of awareness and responsibility; (4) fosters the academic experience contributed by the teacher; and (5) inspires learners by means of positive reinforcement from their teacher and reactions to errors and mistakes.

Fourthly, in-depth teacher monitoring during the project phases reveals that both the PBL method and the various teacher feedback practices are considered practical tactics, capable of providing a fuller understanding of students' perceptions and preferences towards teacher feedback within the learning context. In addition, it has the potential to lead the teachers to discover the best practices encouraging students to accept the giving of feedback.

Finally, the paradigm shift from a teacher-centred to a learner-centred approach can result in teacher feedback becoming a vital element of best classroom practice. Additionally, teachers are recommended to enhance the value of their feedback during the learning and teaching process, along with promoting its constructive alignment to learning.

This study therefore recommends the undertaking of further research into this subject, i.e. a similar study could consider the perceptions and preferences of students towards teacher feedback, particularly in relation to learning styles, proficiency levels, and motivation. In addition, it may prove more effective for a future study to explore the types of revisions and correctness produced by participants, along with how these are influenced by teacher feedback. There is also a need for further exploration into students' perspectives concerning peer feedback, as well as factors that influencing such perspectives.

\section{Limitations of the study}

Although this current study has resulted in a number of significant findings, caution should be taken towards the possibility of their generalization, due to the study focusing on a limited number of EFL student teachers attending EDP in Saudi Arabia. In addition, the Saudi female EFL student teachers taking part in this study were postgraduate students, which may also result in the results not being generalizable to students at undergraduate level. Moreover, the participants consisted exclusively of female students and the potential impact of gender is beyond the scope of this current study.

\section{Acknowledgements}

The researcher wishes to thank the students involved in this study for their willingness to participate, along with the experts who helped in validating the research instruments. Thanks are also extended to the EDP 
administration for the provision of the required information.

\section{References}

Abad, A., Ghosh, A., Riccardi, G., \& Trento, P. (2013). Motivational feedback in crowdsourcing: The case study of speech transcriptions. In In: Proceedings of the 14th Annual Conference of the International Speech Communication Association (INTERSPEECH), pp. 1111-1115.

Bas, G. (2011). Investigating the effects of project-based learning on students' academic achievement and attitudes towards English lesson. The Online Journal of New Horizon in Education, 1(4), 1-15.

Baş, G., \& Beyhan, Ö. (2010). Effects of multiple intelligences supported project-based learning on students' achievement levels and attitudes towards English lesson. International Electronic Journal of Elementary Education, 2(3), 365-385.

Boud, D. (2006). 'Aren't we all learner-centred now?': The bittersweet flavour of success. In changing higher education: The development of learning and teaching. (P. Ashwin, Ed.). New York: Routledge, Taylor \& Francis.

Brown, E., \& Glover, C. (2006). Evaluating written feedback. In C. Bryan \& K. Clegg (Eds.), Innovative Assessment in Higher Education (pp. 80-91). New York, NY: Routledge, Taylor \& Francis.

Carless, D. (2006). Differing perceptions in the feedback process. Studies in Higher Education, 31(2), $219-233$. https://doi.org/10.1080/03075070600572132

Chen, S., Nassaji, H., \& Liu, Q. (2016). EFL learners' perceptions and preferences of written corrective feedback: A case study of university students from Mainland China. Asian-Pacific Journal of Second and Foreign Language Education, 1(1), 1-17. https://doi.org/10.1186/s40862-016-0010-y

Clark, A.-M. (2006). Changing classroom practice to include the project approach. Early Childhood Research \& Practice, 8(2). Retrieved from http://ecrp.uiuc.edu/v8n2/clark.html

Dargusch, J., \& Davis, S. (2015). Feedback, iterative processing and academic trust - teacher education students' perceptions of assessment feedback. Australian Journal of Teacher Education, 40(1), 177-191. https://doi.org/10.14221/ajte.2015v40n1.10

Defalco, J. A., Baker, R. S., Paquette, L., \& Georgoulas, V. (2014). Motivational feedback designs for frustration in a simulation-based combat medic training environment. In In Generalized Intelligent Framework for Tutoring (GIFT) Users Symposium (GIFTSym3) (p. 81).

Douglas, T., Salter, S., Iglesias, M., Dowlman, M., \& Eri, R. (2016). The feedback process: Perspectives of first and second year undergraduate students in the disciplines of education, health science and nursing. Journal of University Teaching \& Learning Practice, 13(1), 1-19. Retrieved from http://ro.uow.edu.au/jutlp/vol13/iss1/3

Eguchi, M., \& Eguchi, K. (2006). The limited effect of PBL on EFL learners: A case study of English magazine projects. Asian EFL Journal, 8(3), 207-225.

Ertmer, P. A., Richardson, J. C., Belland, B., Camin, D., Connolly, P., Coulthard, G., Lei, K. (2007). Using peer feedback to enhance the quality of student online postings : An exploratory study. Journal of ComputerMediated Communication, (12), 412-433. https://doi.org/10.1111/j.1083-6101.2007.00331.x

Fakeye, D. O. (2016). Secondary school teachers' and students' attitudes towards formative assessment and corrective feedback in English language in Ibadan Metropolis. Journal of Educational and Social Research, 6(2), 141-148. https://doi.org/10.5901/jesr.2016.v6n2p141

Ferguson, P. (2011). Student perceptions of quality feedback in teacher education. Assessment and Evaluation in Higher Education, 36(1), 51-62. https://doi.org/10.1080/02602930903197883

Ferris, D. (1999). The case for grammar correction in L2 writing classes : A response to Truscott (1996). Journal of Second Language Writing, 8(1), 1-11.

González, E. F. (2010). Impact of teacher \& student conferencing and teacher written feedback on EFL revision. MEXTESOL Journal, 34(1), 59-74.

Grami, G. M. A. (2005). The effect of teachers' written feedback on ESL students' perception: A study in a Saudi ESL university-level context. Annual Review of Education, Communication and Language Sciences, 2(1), 10-13.

Grant, M. M. (2011). Learning, beliefs, and products: Students' perspectives with project-based learning. Interdisciplinary Journal of Problem-Based Learning, 5(2), 37-69. https://doi.org/10.7771/1541-5015.1254

Hasani, A., Hendrayana, A., \& Senjaya, A. (2017). Using project-based learning in writing an educational article: An experience report. Universal Journal of Educational Research, 5(6), 960-964. https://doi.org/10.13189/ujer.2017.050608

Hattie, J., \& Timperley, H. (2007). The power of feedback. Review of Educational Research, 77(1), 81-112. https://doi.org/10.3102/003465430298487

Hewitt, D. (2008). Understanding effective learning: Strategies for the classroom. Berkshire: McGraw-Hill House. Retrieved from http://books.google.com/books?id=6x5ua4WMQswC\&pgis=1 
Hill, J. D., \& Flynn, K. M. (2006). Classroom instruction that works with English language learners. Alexandria, USA: Association for Supervision and Curriculum Development.

Hixson, N. K., Ravitz, J., \& Whisman, A. (2012). Extended Professional Development in Project-Based Learning. Charleston, WV. Retrieved from http://wvde.state.wv.us/

Holm, M. (2011). Project-based instruction: A review of the literature on effectiveness in prekindergarten through 12th grade classrooms. InSight: Rivier Academic Journal, 7(2), 1-13.

Hooper, D. (2010). Towards an understanding of students' use of audio feedback: An exploratory study. In presented at iCERi2010, 15-17 November, Madrid, Spain (pp. 15-17).

Hüttel, H., \& Gnaur, D. (2017). If PBL is the solution, then what is the problem? Journal of Problem Based Learning in Higher Education, 5(2), 1-21. Retrieved from http://dx.doi.org/10.1007/978-3-642-12107-4_2

Jodaie, M. (2014). Iranian EFL high school students' perceptions regarding written grammar feedback. The Journal of Applied Linguistics, 5(11), 64-84.

Kahraman, A., \& Yalvaç, F. (2015). EFL Turkish university students' preferences about teacher feedback and its importance. Procedia - Social and Behavioral Sciences, 199, 73-80. https://doi.org/10.1016/j.sbspro.2015.07.489

Kaivanpanah, S., Alavi, S. M., \& Sepehrinia, S. (2015). Preferences for interactional feedback: differences between learners and teachers. Language Learning Journal, 43(1), 74-93. https://doi.org/10.1080/09571736.2012.705571

Kaur, M., \& Singh, M. (2016). Graduate students' needs and preferences for written feedback on academic writing. English Language Teaching, 9(12), 79-88. https://doi.org/10.5539/elt.v9n12p79

Kavaliauskienè, G., \& Anusienè, L. (2012). Case study: Learner attitudes towards the correction of mistakes. Social Technologies, 2(1), 88-101.

Larmer, J., \& Mergendoller, J. R. (2010). Seven essentials for project-based learning. Educational Leadership, 68(1), 34-37. $\quad$ Retrieved from http://www.ascd.org/publications/educational_leadership/sept10/vol68/num01/Seven_Essentials_for_Projec t-Based_Learning.aspx

Lee, T. Y., Dugan, C., Geyer, W., Ratchford, T., Rasmussen, J., Shami, N. S., \& Lupushor, S. (2013). Experiments on motivational feedback for crowdsourced workers. Proceedings of the $7^{\text {th }}$ International Conference on Weblogs and Social Media, ICWSM 2013, 341-350. Retrieved from http://www.scopus.com/inward/record.url?eid=2-s2.0-84900388998\&partnerID=tZOtx3y1

Lipnevich, A. A., \& Smith, J. K. (2009). Effects of differential feedback on students' examination performance. Journal of Experimental Psychology: Applied, 15(4), 319-333. https://doi.org/10.1037/a0017841

Merry, S., \& Orsmond, P. (2008). Students' attitudes to and usage of academic feedback provided via audio files. Bioscience Education, 11(1), 1-11. https://doi.org/10.3108/beej.11.3

Morss, K., \& Murray, R. (2005). Teaching at university: A guide for postgraduates and researchers. London: SAGE Publications.

Moss, D., \& Van Duzer, C. (1998). Project-based learning for adult English language learners. ERIC Digest ED427556, 1-7. Retrieved from www.eric.ed.gov

Mungungu-Shipale, S. S., \& Kangira, J. (2017). Lecturers' and students' perceptions and preferences about ESL corrective feedback in Namibia: Towards an intervention model. World Journal of English Language, 7(1), 11. https://doi.org/10.5430/wjel.v7n1p11

Narciss, S. (2008). Feedback strategies for interactive learning tasks. Handbook of Research on Educational Communications and Technology, 125-144. https://doi.org/10.4324/9780203880869.ch1 1

Nation, I. S. P. (2009). Teaching ESL / EFL reading and writing. New York, NY: Routledge, Taylor \& Francis.

New South Wales Government. (2015). Types of feedback: Strong start, great teachers - Phase 3. State of New South Wales. Retrieved from www.ssgt.nsw.edu.au/documents/1types_feedback.pdf

Norouzian, R., \& Farahani, A. A. K. (2012). Written error feedback from perception to practice: A feedback on feedback. Journal of Language Teaching and Research, 3(1), 11-22. https://doi.org/10.4304/j1tr.3.1.11-22

Nuramirah, P. (2017). An analysis of teacher's corrective feedback and learners' uptake in dialogue journal. Social Science, Education and Humanities Research (ASSEHR), 82(Conaplin 9), 308-310.

Orts, S., \& Salazar, P. (2016). EFL students' preferences towards written corrective feedback: An exploratory study on age and level of proficiency. The Grove - Working Papers on English Studies, 23, 109-129. https://doi.org/10.17561/grove.v23.a8

Papangkorn, P. (2015). SSRUIC students' attitude and preference toward error corrections. Procedia - Social and Behavioral Sciences, 197(February), 1841-1846. https://doi.org/10.1016/j.sbspro.2015.07.244

Park, G. (2010). Preference of corrective feedback approaches perceived by Native English teachers and students. The Journal of Asia TEFL, 7(4), 29-52.

Parkes, M., \& Fletcher, P. (2016). A longitudinal, quantitative study of student attitudes towards audio feedback for assessment. Assessment and Evaluation in Higher Education, 42(7), 1046-1053. 
https://doi.org/10.1080/02602938.2016.1224810

Petchprasert, A. (2012). Feedback in second language teaching and learning. US-China Foreign Language, 10(4), 1112-1120. Retrieved from http://www.davidpublishing.com/davidpublishing/Upfile/6/8/2012/2012060806317598.pdf

Pieratt, J. R. (2010). Advancing the ideas of John Dewey: A look at the high tech schools. Education and Culture, 26(2), 52-64.

Postholm, M. B. (2005). The teacher shaping and creating dialogues in project work. Teachers and Teaching: Theory and Practice, 11(6), 519-539. https://doi.org/http://dx.doi.org/10.1080/13450600500293217

Rahimi, M. (2010). Iranian EFL Students' Perceptions and Preferences for Teachers' Written Feedback: Do Students' ideas Reflect Teachers' Practice? The Journal of Teaching Language Skills (JTLS), 2(2), 75-98.

Ravitz, J. (2010). Beyond changing culture in small high schools: Reform models and changing instruction with project-based learning. Peabody Journal of Education, 85(3), $290-312$. https://doi.org/10.1080/0161956X.2010.491432

Rowe, A. D., \& Wood, L. N. (2008). Student perceptions and preferences for feedback. Asian Social Science, 4(3), 78-88. https://doi.org/10.5539/ass.v4n3p78

Rowe, A. D., Wood, L. N., \& Petocz, P. (2008). Engaging students: Student preferences for feedback, in engaging communities. In Proceedings of the 31st HERDSA Annual Conference (pp. 297-306). Retrieved from

http://search.proquest.com.ezproxy.canterbury.ac.nz/docview/1023240692/fulltextPDF/6B8908F592ED438 DPQ/1? accountid=14499

Şat, M. (2013). CEIT undergraduate students' perceptions and preferences of formative feedback, and the relationship of these perceptions and preferences with their learning approaches. Middle East Technical University.

Seker, M., \& Dincer, A. (2014). An insight to students' perceptions on teacher feedback in second language writing classes. English Language Teaching, 7(2), 73-83. https://doi.org/10.5539/elt.v7n2p73

Şeker, M., \& Sezgin, M. E. (2013). Investigating students' perceptions on feedback in distance education program: A case study in Turkey. Sosyal Bilimler Enstitüsü Dergisi, 22(1), 513-528.

Sharif, A. M., \& Zainuddin, S. Z. (2017). Students' perceptions of their reflective essay writing experience and teacher feedback comments. Indonesian Journal of Applied Linguistics, 6(2), $204-212$. https://doi.org/10.17509/ijal.v6i2.4845

Simpson, J. (2011). Integrating project-based learning in an English language tourism classroom in a Thai University. Australian Catholic University.

Solomon, G. (2003). Project-based learning: A primer. Retrieved from http://www.techlearning.com/db_area/archives/TL/2003/01/project.php

Sopin, G. (2015). Perceptions and preferences of ESL students regarding the effectiveness of corrective feedback in Libyan secondary schools. IOSR Journal of Research \& Method in Education Ver. II, 5(4), 2320-7388. https://doi.org/10.9790/7388-05427177

Susanti, R. (2013). Students' perceptions towards the effective feedback practices in the large EFL writing class based on participation, gender, and English proficiency level. Thesis. Indiana University of Pennsylvania, School of Graduate Studies and Research.

Tamba, P., Motlan, \& Turnip, B. (2017). The effect of project based learning model for students' creative thinking skills and problem solving. IOSR Journal of Research \& Method in Education (IOSR-JRME), 7(5), 67-70. https://doi.org/10.9790/7388-0705026770

Thomas, J. W. (2000). A review of research on project-based learning. San Rafael, California. https://doi.org/10.1007/s11528-009-0302-x

Truscott, J. (1996). The case of grammar correction in L2 writing classes. Language Learning, 46(2), 327-369. https://doi.org/10.1016/S1060-3743(99)80124-6

Vasu, K., Ling, C. H., \& Nimehchisalem, V. (2016). Malaysian tertiary level ESL students' perceptions toward teacher feedback, peer feedback and self-assessment in their writing. International Journal of Applied Linguistics and English Literature, 5(5), 158-170. https://doi.org/10.7575/aiac.ijalel.v.5n.5p.158

Watts, S. A. (2007). Evaluative feedback: Perspectives on media effects. Journal of Computer-Mediated Communication, 12(2), 50-77. https://doi.org/10.1111/j.1083-6101.2007.00330.x

Westwood, P. (2008). What teachers need to know about learning difficulties. Victoria, Australia: ACER Press. https://doi.org/9780864319364

Wrigley, H. S. (1998). Knowledge in action: The promise of project-based learning. National Center for the Study of Adult Learning and Literacy (NCSALL), 2(D). Retrieved from http://ncsall.net/index.php@id=384.html

Zacharias, N. T. (2007). Teacher and student attitudes toward teacher feedback. RELC Journal, 38(1), 38-52. https://doi.org/10.1177/0033688206076157 
Zancul, E. de S., Sousa-Zomer, T. T., \& Cauchick-Miguel, P. A. (2017). Project-based learning approach: improvements of an undergraduate course in new product development. Production, 27((spe)), 1-14. https://doi.org/http://dx.doi.org/10.1590/0103-6513.225216

Zhan, L. (2016). Written teacher feedback: Student perceptions, teacher perceptions, and actual teacher performance. English Language Teaching, 9(8), 73-84. https://doi.org/10.5539/elt.v9n8p73

Appendix (A)

Results of the Course Evaluation University Questionnaire (CEUQ)

\begin{tabular}{|c|c|c|c|c|c|c|c|c|}
\hline Statements & $\begin{array}{c}\text { Strongly } \\
\text { agree }\end{array}$ & Agree & Neutral & Disagree & $\begin{array}{l}\text { Strongly } \\
\text { disagree }\end{array}$ & Mean & S.D. & $\begin{array}{c}\text { Average } \\
\text { Mean \& } \\
\text { S.D. }\end{array}$ \\
\hline \multicolumn{9}{|l|}{ Beginning of the Course } \\
\hline $\begin{array}{l}\text { 1. The basic lines } \\
\text { including the information } \\
\text { and skills in the course } \\
\text { were clear to my future } \\
\text { career. }\end{array}$ & $\begin{array}{c}30 \\
(96.77)\end{array}$ & - & $\begin{array}{c}1 \\
(3.23)\end{array}$ & - & - & 4.94 & 0.36 & \multirow{3}{*}{$\begin{array}{l}\mathrm{M}=4.93 \\
\mathrm{SD}=0.30\end{array}$} \\
\hline $\begin{array}{l}\text { 2. The requirements for } \\
\text { success in the course were } \\
\text { clear to me. }\end{array}$ & $\begin{array}{c}29 \\
(93.54)\end{array}$ & $\begin{array}{c}2 \\
(6.46)\end{array}$ & - & - & - & 4.94 & 0.25 & \\
\hline $\begin{array}{l}\text { 3. The course resources } \\
\text { including office hours, } \\
\text { references were clear to } \\
\text { me. }\end{array}$ & $\begin{array}{c}28 \\
(90.32)\end{array}$ & $\begin{array}{c}3 \\
(9.68)\end{array}$ & - & - & - & 4.90 & 0.30 & \\
\hline \multicolumn{9}{|l|}{ Implementation of the Course } \\
\hline $\begin{array}{l}\text { 4. The requirements were } \\
\text { consistent with the outline } \\
\text { of the course. }\end{array}$ & $\begin{array}{c}29 \\
(93.54)\end{array}$ & $\begin{array}{c}1 \\
(3.23)\end{array}$ & - & $\begin{array}{c}1 \\
(3.23)\end{array}$ & - & 4.87 & 0.56 & \multirow{10}{*}{$\begin{array}{l}M=4.77 \\
\mathrm{SD}=0.56\end{array}$} \\
\hline $\begin{array}{l}\text { 5. The teacher was } \\
\text { committed to give the } \\
\text { course fully (e.g., } \\
\text { lecturing on time, good } \\
\text { preparation, etc.). }\end{array}$ & $\begin{array}{c}26 \\
(83.87)\end{array}$ & $\begin{array}{c}4 \\
(12.90)\end{array}$ & $\begin{array}{c}1 \\
(3.23)\end{array}$ & - & - & 4.81 & 0.48 & \\
\hline $\begin{array}{l}\text { 6. The course has full } \\
\text { knowledge of the course } \\
\text { content. }\end{array}$ & $\begin{array}{c}30 \\
(96.77)\end{array}$ & - & - & $\begin{array}{c}1 \\
(3.23)\end{array}$ & - & 4.90 & 0.54 & \\
\hline $\begin{array}{l}\text { 7. The teacher was } \\
\text { available to assist during } \\
\text { office hours. }\end{array}$ & $\begin{array}{c}28 \\
(90.32)\end{array}$ & $\begin{array}{c}2 \\
(6.46)\end{array}$ & $\begin{array}{c}1 \\
(3.23)\end{array}$ & $\begin{array}{c}0 \\
(0.0)\end{array}$ & - & 4.87 & 0.43 & \\
\hline $\begin{array}{l}\text { 8. The teacher was } \\
\text { enthusiastic about what to } \\
\text { teach. }\end{array}$ & $\begin{array}{c}27 \\
(87.10)\end{array}$ & $\begin{array}{c}4 \\
(12.90)\end{array}$ & - & - & - & 4.87 & 0.34 & \\
\hline $\begin{array}{l}\text { 9. The teacher was } \\
\text { interested in my progress } \\
\text { in the course. }\end{array}$ & $\begin{array}{c}26 \\
(83.87)\end{array}$ & $\begin{array}{c}3 \\
(9.68)\end{array}$ & $\begin{array}{c}2 \\
(6.46)\end{array}$ & - & - & 4.77 & 0.56 & \\
\hline $\begin{array}{l}\text { 10. Everything presented } \\
\text { in the course was recent } \\
\text { and useful. }\end{array}$ & $\begin{array}{c}25 \\
(80.65)\end{array}$ & $\begin{array}{c}3 \\
(9.68)\end{array}$ & $\begin{array}{c}2 \\
(6.46)\end{array}$ & - & $\begin{array}{c}1 \\
(3.23)\end{array}$ & 4.65 & 0.88 & \\
\hline $\begin{array}{l}\text { 11. The resources of this } \\
\text { course were available } \\
\text { whenever I needed. }\end{array}$ & $\begin{array}{c}24 \\
(77.42)\end{array}$ & $\begin{array}{c}3 \\
(9.68)\end{array}$ & $\begin{array}{c}4 \\
(12.90)\end{array}$ & - & - & 4.65 & 0.71 & \\
\hline $\begin{array}{l}\text { 12. There was an effective } \\
\text { use of technology to } \\
\text { support the course. }\end{array}$ & $\begin{array}{c}27 \\
(87.10)\end{array}$ & $\begin{array}{c}1 \\
(3.23)\end{array}$ & $\begin{array}{c}3 \\
(9.68)\end{array}$ & - & - & 4.77 & 0.62 & \\
\hline $\begin{array}{l}\text { 13. I was encouraged to } \\
\text { ask questions in this } \\
\text { course. }\end{array}$ & $\begin{array}{c}27 \\
(87.10)\end{array}$ & $\begin{array}{c}2 \\
(6.46)\end{array}$ & $\begin{array}{c}2 \\
(6.46)\end{array}$ & - & - & 4.81 & 0.54 & \\
\hline
\end{tabular}




\begin{tabular}{|c|c|c|c|c|c|c|c|c|}
\hline Statements & $\begin{array}{c}\text { Strongly } \\
\text { agree }\end{array}$ & Agree & Neutral & Disagree & $\begin{array}{l}\text { Strongly } \\
\text { disagree }\end{array}$ & Mean & S.D. & $\begin{array}{l}\text { Average } \\
\text { Mean \& } \\
\text { S.D. }\end{array}$ \\
\hline $\begin{array}{l}\text { 14. In this course, I was } \\
\text { encouraged to show my } \\
\text { best performance. }\end{array}$ & $\begin{array}{c}28 \\
(90.32)\end{array}$ & $\begin{array}{c}1 \\
(3.23)\end{array}$ & $\begin{array}{c}2 \\
(6.46)\end{array}$ & - & - & 4.84 & 0.52 & \\
\hline $\begin{array}{l}\text { 15. The requirements in } \\
\text { this course helped me } \\
\text { develop my knowledge } \\
\text { and skills. }\end{array}$ & $\begin{array}{c}24 \\
(77.42)\end{array}$ & $\begin{array}{c}6 \\
(19.35)\end{array}$ & $\begin{array}{c}1 \\
(3.23)\end{array}$ & - & - & 4.74 & 0.51 & \\
\hline $\begin{array}{l}\text { 16. The amount of work } \\
\text { was appropriate to the } \\
\text { course credit hours. }\end{array}$ & $\begin{array}{c}22 \\
(70.97)\end{array}$ & $\begin{array}{c}5 \\
(16.13)\end{array}$ & $\begin{array}{c}4 \\
(12.90)\end{array}$ & - & - & 4.58 & 0.72 & \\
\hline $\begin{array}{l}\text { 17. The grades of } \\
\text { assignments and tests in } \\
\text { this course were submitted } \\
\text { to me within a reasonable } \\
\text { time. }\end{array}$ & $\begin{array}{c}27 \\
(87.10)\end{array}$ & $\begin{array}{c}4 \\
(12.90)\end{array}$ & - & - & - & 4.87 & 0.34 & \\
\hline $\begin{array}{l}\text { 18. The correction of my } \\
\text { assignments and tests was } \\
\text { fair and appropriate. }\end{array}$ & $\begin{array}{c}28 \\
(90.32)\end{array}$ & $\begin{array}{c}3 \\
(9.68)\end{array}$ & - & - & - & 4.90 & 0.30 & \\
\hline $\begin{array}{l}\text { 19. The relationship } \\
\text { between this course and } \\
\text { other courses in the } \\
\text { program was clear to me. }\end{array}$ & $\begin{array}{c}21 \\
(67.74)\end{array}$ & $\begin{array}{c}5 \\
(16.13)\end{array}$ & $\begin{array}{c}3 \\
(9.68)\end{array}$ & $\begin{array}{c}2 \\
(6.46)\end{array}$ & - & 4.45 & 0.93 & \\
\hline \multicolumn{9}{|l|}{ Course Content Evaluation } \\
\hline $\begin{array}{l}20 . \text { What I learned in this } \\
\text { course is important and } \\
\text { beneficial to me. }\end{array}$ & $\begin{array}{c}20 \\
(64.52)\end{array}$ & $\begin{array}{c}4 \\
(12.90)\end{array}$ & $\begin{array}{c}5 \\
(16.13)\end{array}$ & $\begin{array}{c}1 \\
(3.23)\end{array}$ & $\begin{array}{c}1 \\
(3.23)\end{array}$ & 4.32 & 1.08 & \multirow{4}{*}{$\begin{array}{l}\mathrm{M}=4.57 \\
\mathrm{SD}=0.79\end{array}$} \\
\hline $\begin{array}{l}\text { 21. This course helped me } \\
\text { improve my ability to } \\
\text { think and solve problems. }\end{array}$ & $\begin{array}{c}20 \\
(64.52)\end{array}$ & $\begin{array}{c}5 \\
(16.13)\end{array}$ & $\begin{array}{c}4 \\
(12.90)\end{array}$ & $\begin{array}{c}2 \\
(6.46)\end{array}$ & - & 4.39 & 0.95 & \\
\hline $\begin{array}{l}\text { 22. This course helped me } \\
\text { improve my teamwork } \\
\text { skills. }\end{array}$ & $\begin{array}{c}25 \\
(80.65)\end{array}$ & $\begin{array}{c}5 \\
(16.13)\end{array}$ & - & $\begin{array}{c}1 \\
(3.23)\end{array}$ & - & 4.74 & 0.63 & \\
\hline $\begin{array}{l}\text { 23. This course helped me } \\
\text { improve my ability to } \\
\text { communicate effectively. }\end{array}$ & $\begin{array}{c}26 \\
(83.87)\end{array}$ & $\begin{array}{c}4 \\
(12.90)\end{array}$ & $\begin{array}{c}1 \\
(3.23)\end{array}$ & $\begin{array}{c}0 \\
(0.0)\end{array}$ & - & 4.81 & 0.48 & \\
\hline \multicolumn{9}{|l|}{ Students' General Satisfaction } \\
\hline $\begin{array}{l}\text { 24. Overall, I am satisfied } \\
\text { with the quality of this } \\
\text { course. }\end{array}$ & $\begin{array}{c}25 \\
(80.65)\end{array}$ & $\begin{array}{c}6 \\
(19.35)\end{array}$ & - & - & - & 4.81 & 0.40 & $\begin{array}{l}\mathrm{M}=4.81 \\
\mathrm{SD}=0.40\end{array}$ \\
\hline
\end{tabular}

